ARID International Journal of Social Sciences and Humanities (AIJSSH) VOL.3, NO.5, January 2021

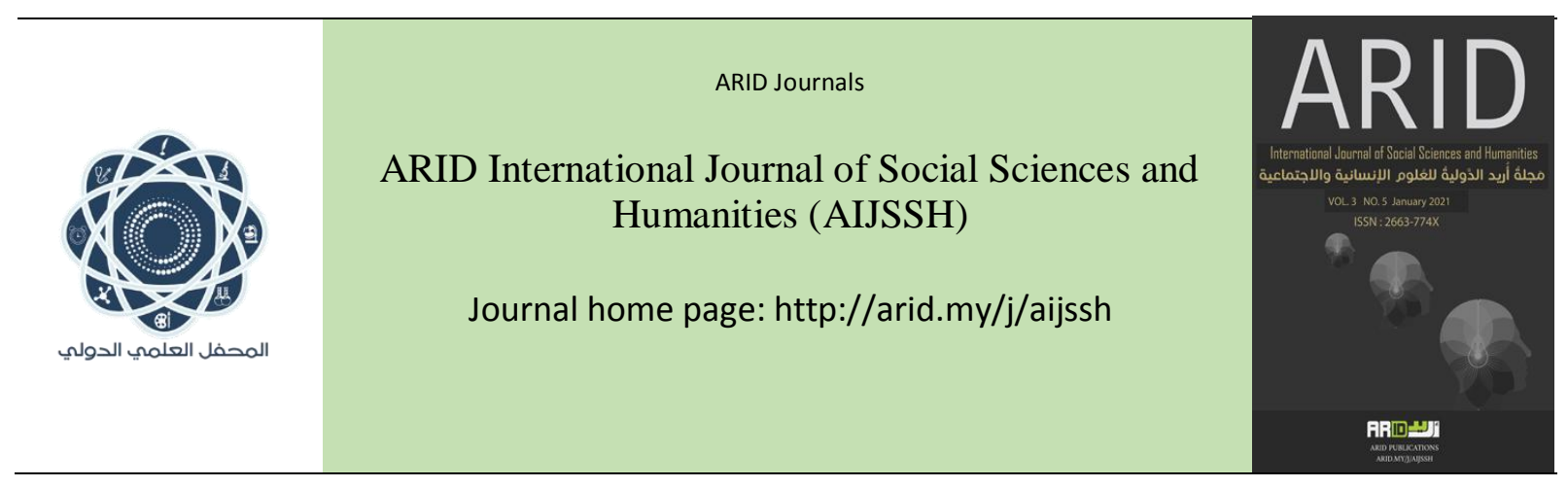

$$
\begin{aligned}
& \text { مَجلةُ أُريد الدَّوليُُّ للعُلومِ الإنسانية والإجتماعية } \\
& \text { البحلد الثالث ،العدد الخامس، كانون الثاني } 2021 \text { م }
\end{aligned}
$$

\title{
The characteristics of Jesus, peace be upon him, in the Holy Quran Objective explanatory study
}

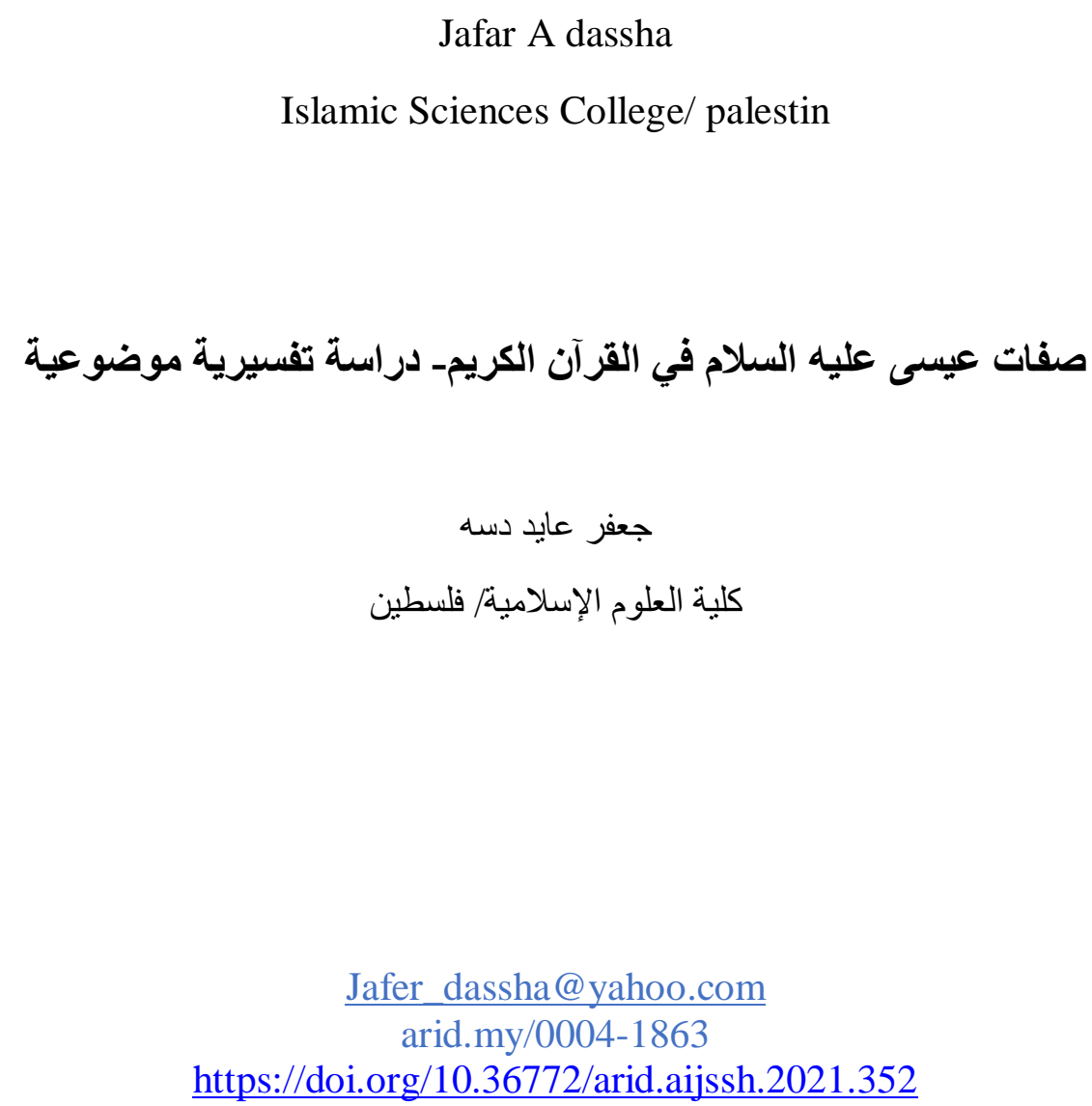

https://doi.org/10.36772/arid.aijssh.2021.352 


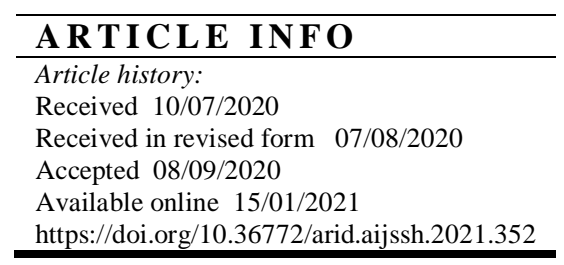

\begin{abstract}
The characteristics of the prophets and their exploitation in the call to God, the best way to follow their example and follow their approach to the call to God Almighty with wisdom and good advice, especially the prophets who have a clear impact in adopting people to invite them, including Isa Ibn Maryam, peace be upon him.
\end{abstract}

Examining his qualities raises hope and confidence in God

Keywords: Da,wha. Jesus . characteristics. 


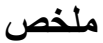

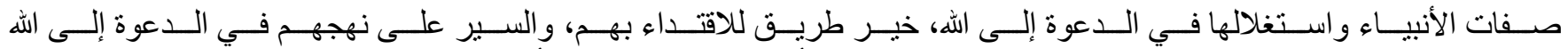

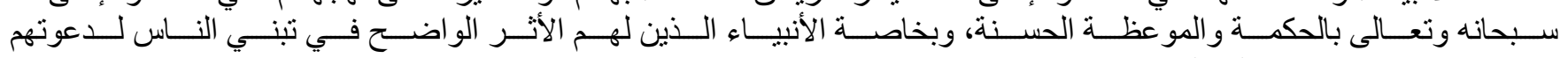
من بينهم عيسى ابن مريم عليه السلام. بانه

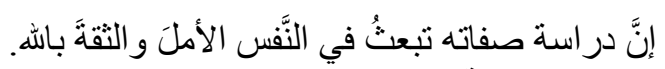

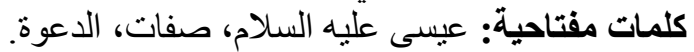




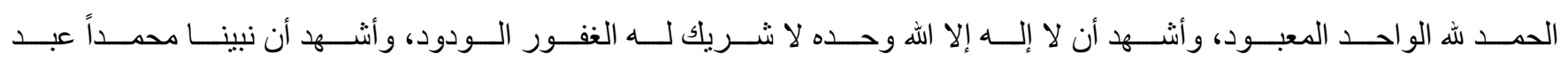
الله ورسوله، صاحب الدقام المحمود، أما بعد....

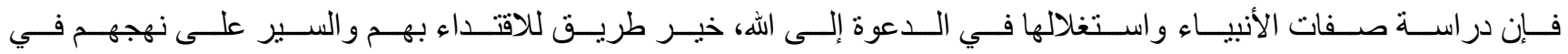

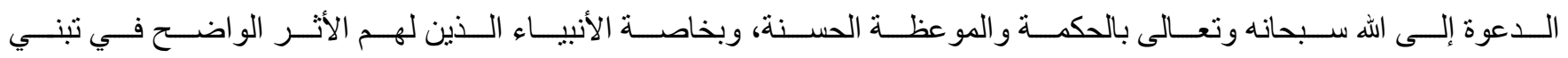
الناس لدعوتهم من بينهم عيسى ابن مريم عليه السلام.

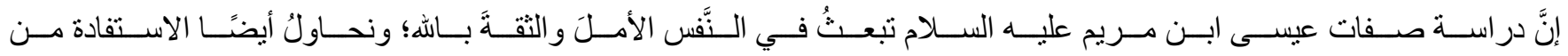

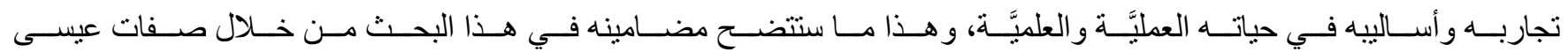
عليه السلام.

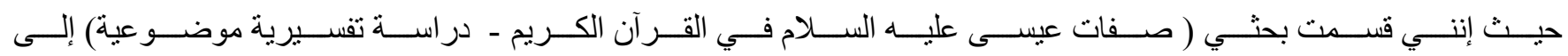

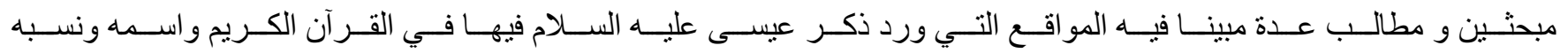
وو لادته والصفات الخلقية والخُلقية وبعض الصفات الإضافية التي اتصف بها خلافا لباقي البشر.

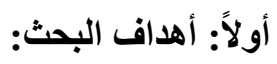

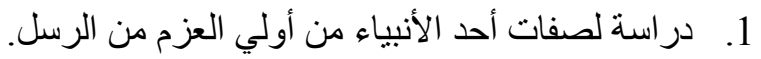
2. إظهار الصفات الخُلقية ليتصف بها من حمل رسالة الدعوة. 3. إنكار على النصارى ما ادعوا به من الألو هية لعيسى عليه السلام.

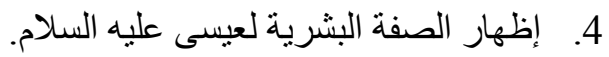

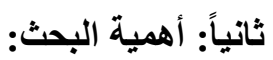

$$
\text { 1. } 1 \text {. بيان اسم عيسى عليه السلام ونسبه. }
$$

3. بيان أهم الموضو عات الدعوية التي دعا إليها عيسى إلى قومه من خلال ما اتصف به. 
ثُالثاً: أسباب اختيار الموضوع:

أردت من خلال بحثي المتو اضع أنْ أُلقي الضَّوْه على موضوع صفات عيسى عليه السلام في القرآن الكريم

التي قل ما يكتب عنها في الأبحاث، وبيانها من خلال در اسة تفسيرية موضو عية، في ظلال القرآن الكريم وبعيدا عن

$$
\text { أكاذيب النصارى وتحريفهر. }
$$

رابعاً : منهجيه البحث:

سأعتمد في بحثي على المنهج الوصفي الاستقر ائي و هو منهج المناسب والأفضل لمثل هذه الدراسات.

خامساً: الاراسات السابقة:

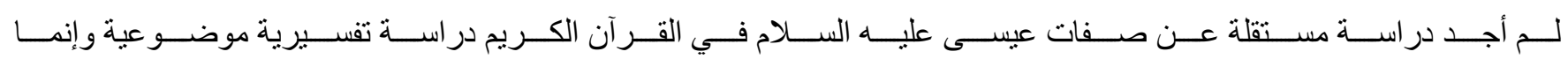

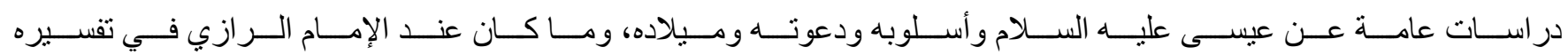
مفاتيح الغيب. ومن بينها:

$$
\begin{aligned}
& \text { 1. نهاية عيسى عليه السلام ودعوته في القرآن والإنجيل: هنا حافظ عبد الغني عبد النبي. } \\
& \text { 2. منهج أولي العزم من الرسل عليهم السلام في الدعوة: معتز محجوب محمد البخاري. } \\
& \text { 3. عيسى ابن مريم في ضوء الكتاب و السنه: منيره حبيب. } \\
& \text { 4. ميلاد عيسى عليه السلام عند اليهود و النصارى و المسلمين: مسعود بن سعد الغامدي. }
\end{aligned}
$$

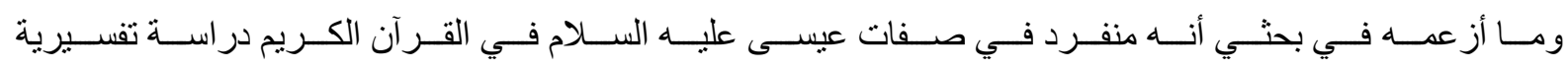

$$
\text { موضوعية. }
$$

\section{سادساً: خطة البحث:}

يتضمن هذا الموضوع مقدمة وتمهيد ومبحثين وخاتمة:

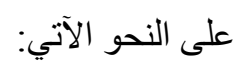

تمهيد : ويتضمن، أهمية البحث و أهدافه، و الدر اسات السابقة، ومنهجية البحث.

المبحث الأول: عيسى عليه السلام في القرآن الكريم وفيه مطالبان:

المطلب الأول: الآيات التي ورد فيها ذكر عيسى عليه السلام.

المطلب الثاني: اسمه ونسبه وو لادته. 
المبحث الثاني: صفات عيسى عليه السلام في القرآن الكريم، وفيه مطالب:

$$
\begin{aligned}
& \text { المطلب الأول: الصفات الخَلْقية. } \\
& \text { المطلب الثاني: الصفات الخُلقية. } \\
& \text { المطلب الثالث: الصفات الإضافية. } \\
& \text { الخاتمة (وتضمنت أهم النتائج والتوصيات) }
\end{aligned}
$$

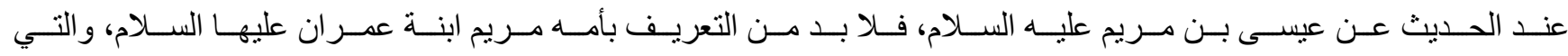

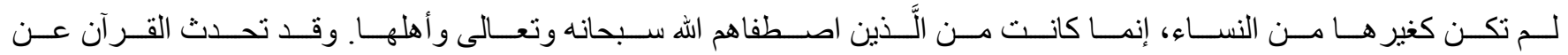

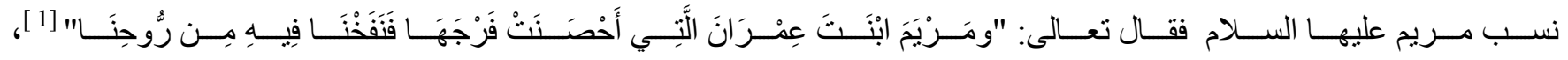

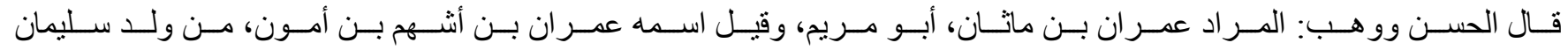

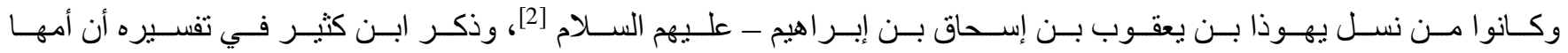

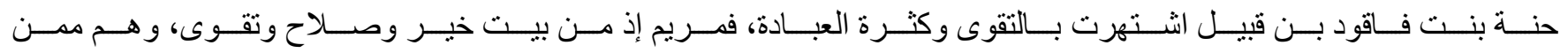

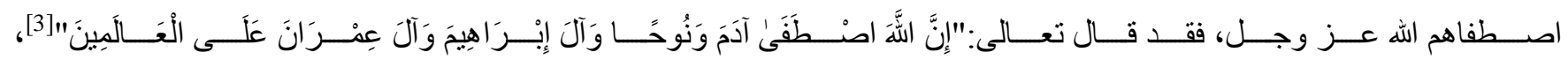
وكان اصطفاء الله لهم بأن اختار هم وفضلهم على العالمين بالنبوة[4].

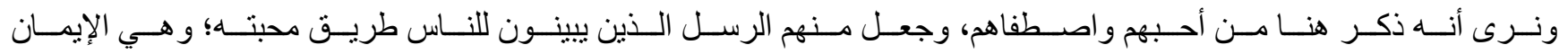
به مع طاعته و العمل بما يرضيه. وقد ذكر المولى في كتابه العزيز ما أنعم على مريم من نعم، ومن ذللك ما كان في شأنها وَوِلادتها وحين كفالتها، حيثُ يقول سبحانه: "

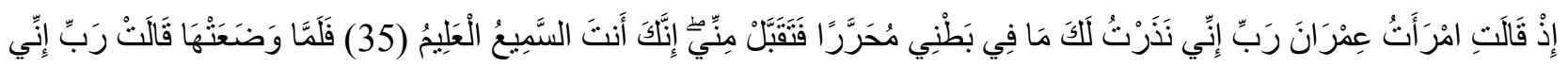

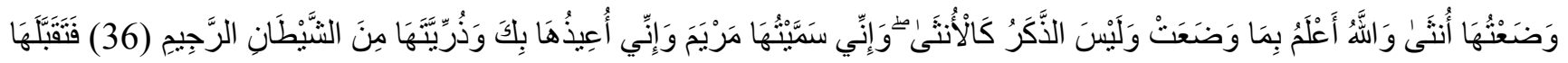

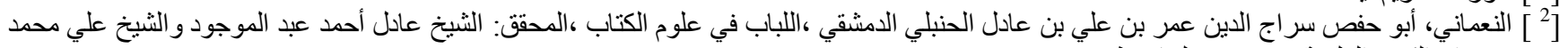

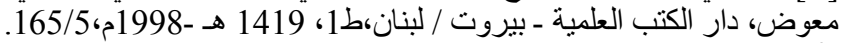
[3 ] [ ابن كثير ، أبو الفذاء إسماعيل بن عمر بن كثير القرشي ، تفسير القر آن العظيم (ابن كثير)،المحقق: محد حسين شمس الدين، دار الكتب العلمية - بيروت، ط1، 


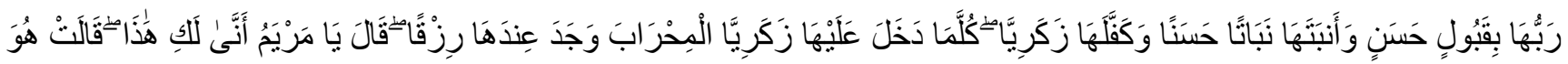

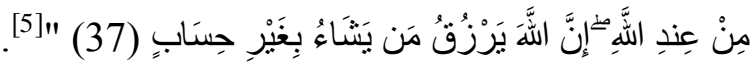

$$
\text { وتتمثل عناية الله سبحانه وتعالى بمريم في هذه الآيات بأمور عدة على النحو التالي:[6] }
$$

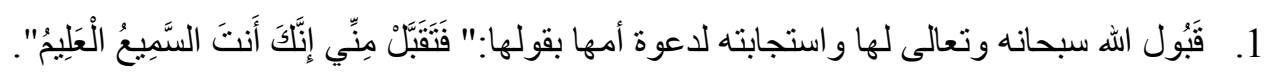
2. أن اله جعل كفالتها بيد نبي من أنبيائه و هو زكريا فكان ذلك من أسباب النشأة الصالحة.

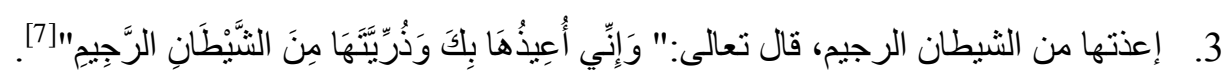

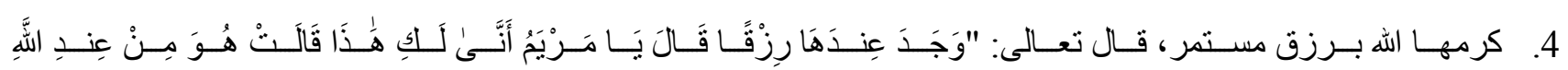

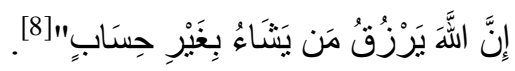
المبحث الأول: عيسى عليه السلام في القرآن الكريم وفيه مطالبان: يورد الباحث الآيات التي وردت في القرآن الكريم ذكر فيها عليه السلام باسمه أو ما كني به. المطلب الأول : الآيات التي ورد فيها ذكر عيسى عليه السلام في القرآن الكريح. ذُكر عبسى باسمه في القرآن 25 مرة خمس وعشرون مرة، ووردت كنيته بالمسيح (10)عشر مر ات، وورد وصف نفسه بعبد الله مرة واحدة.

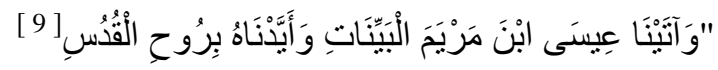

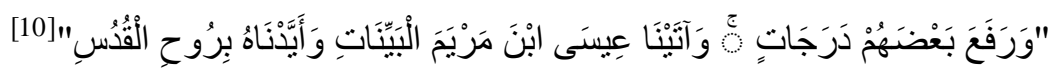

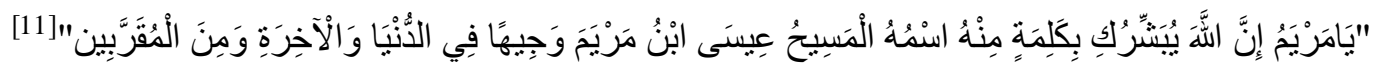

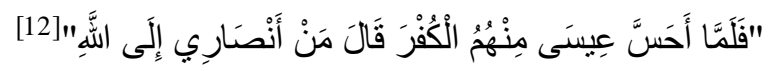

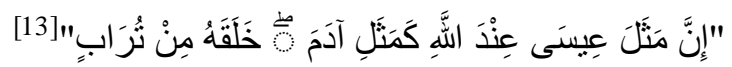

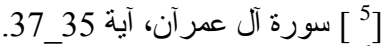

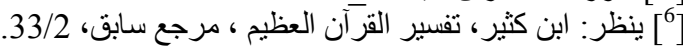

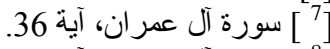

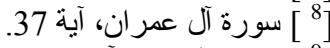

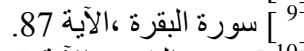
[ ]

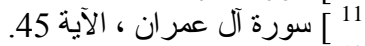

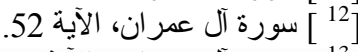




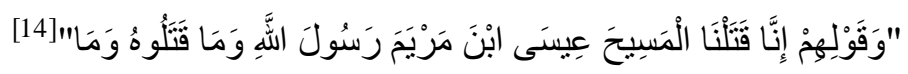

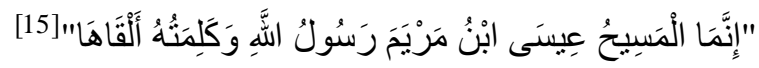

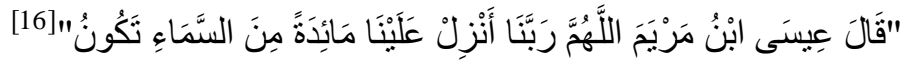

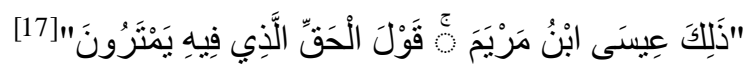

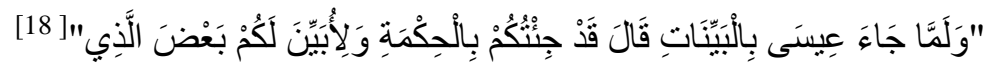

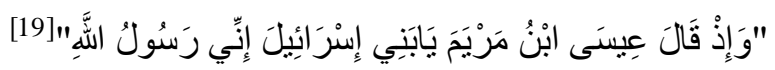

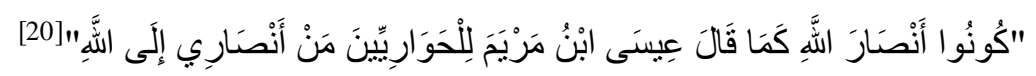

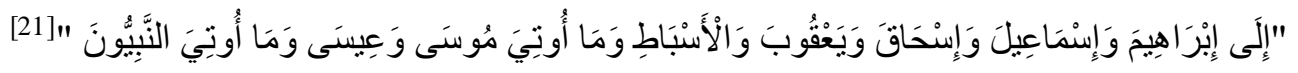

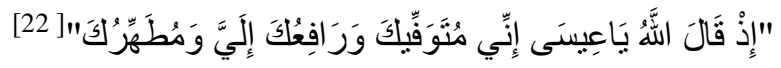

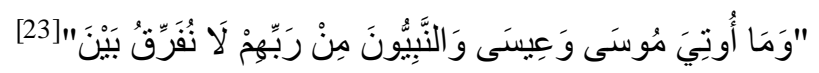

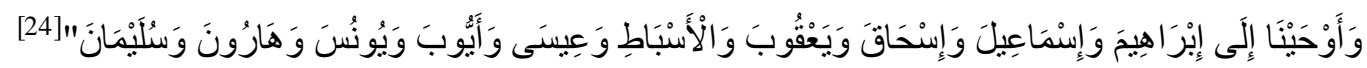

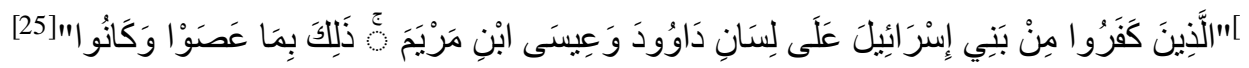

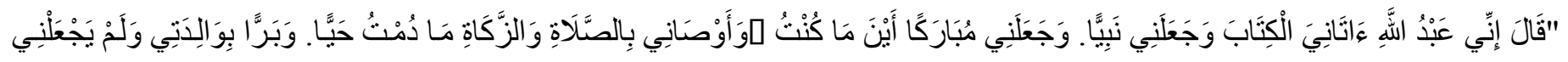

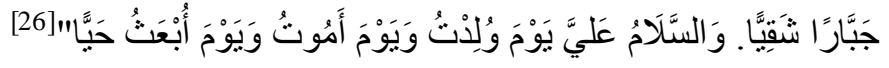




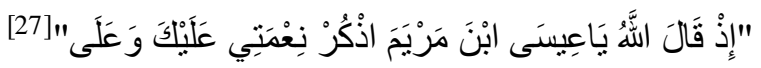

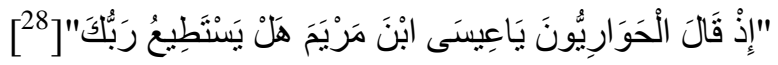

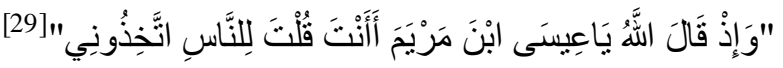

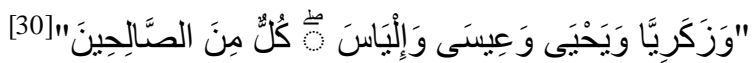

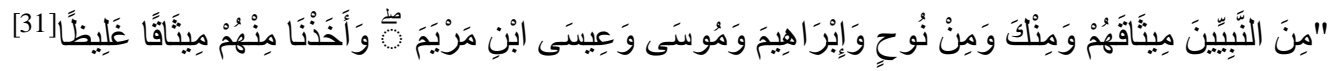

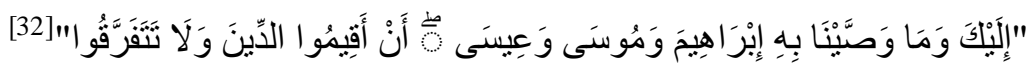

المطلب الثاني: اسمهل ونسبه ولادته.

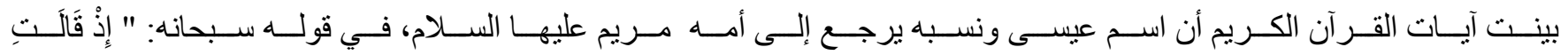

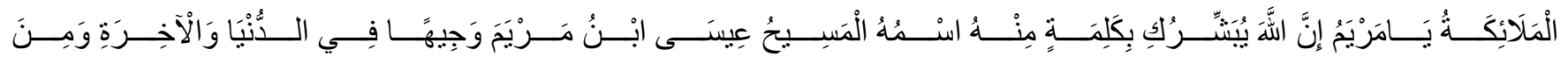

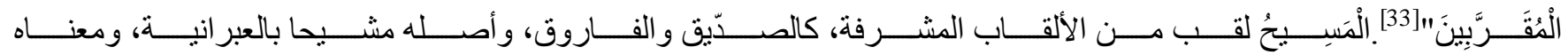

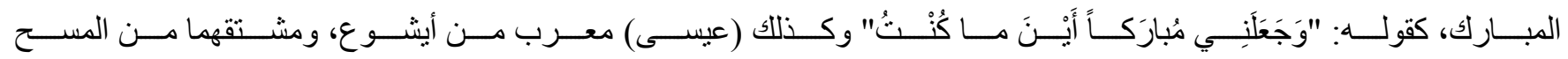
و العيس، فإن قلت: لم قيل: عيسى ابن مريم و الخطاب لمريم؟ 


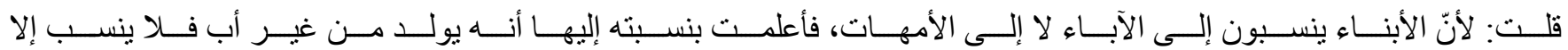

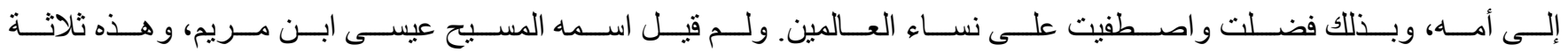

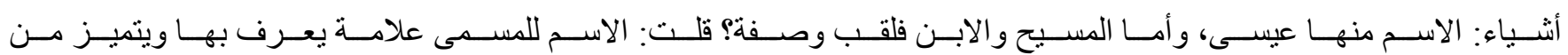

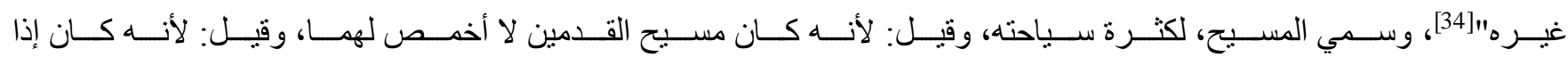

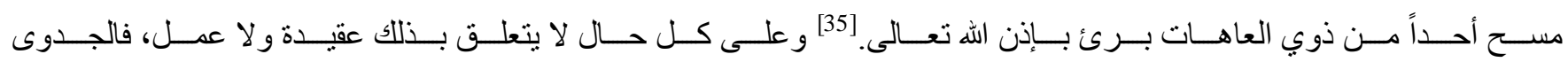
في ذلك ضعيفة أو معدومة.

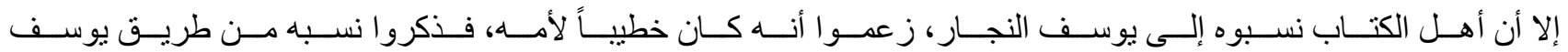
النجار، وفي إنجيل منى وصل نسبه إلى إبراهيم، وفي إنجيل لوقا وصل نسبه إلى آدم عليه السلام. [36]

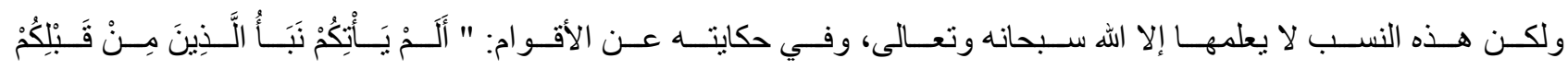

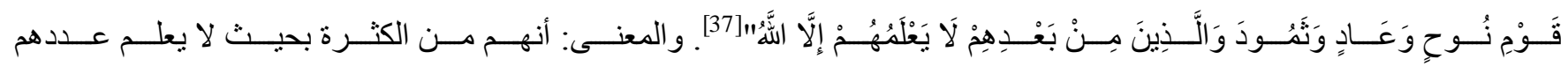

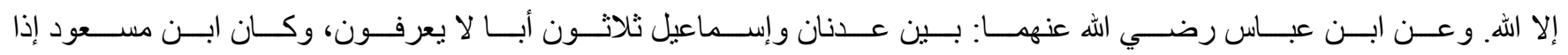
قرأ هذه الآية قال: كذب النسابون، يعني أنهم يدّعون علم الأنساب، وقد نفى الله علمها عن العباد.[38]

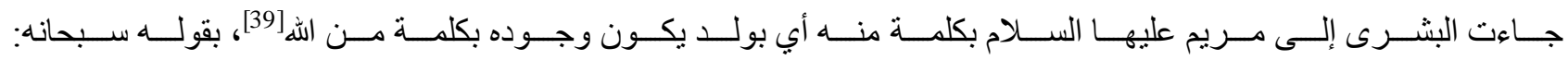

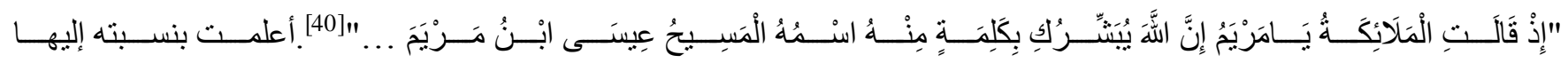

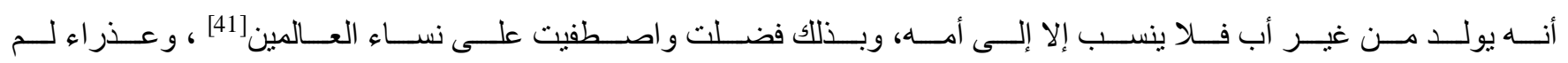

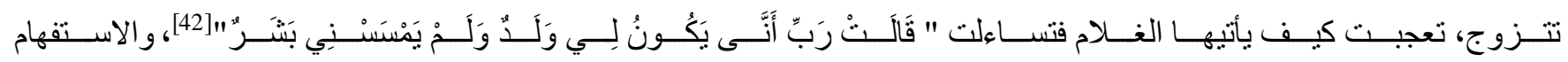

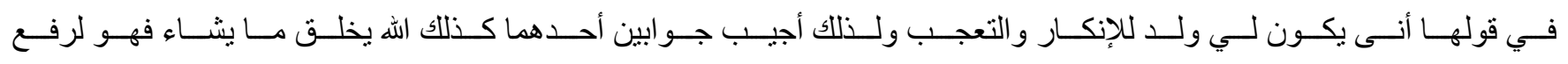

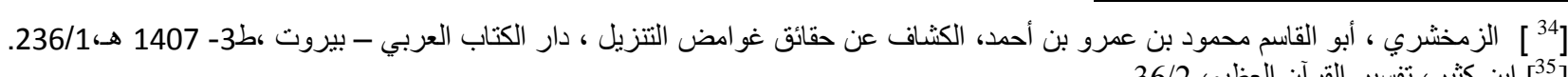

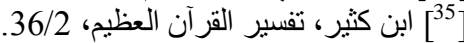

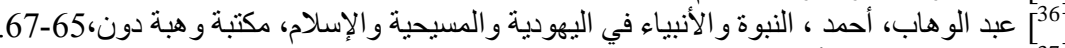
.

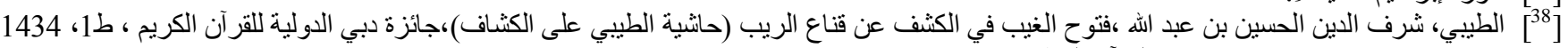

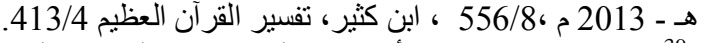

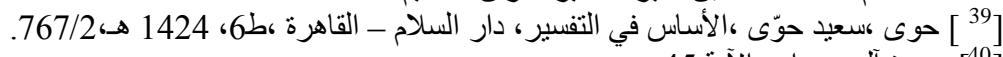

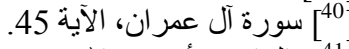

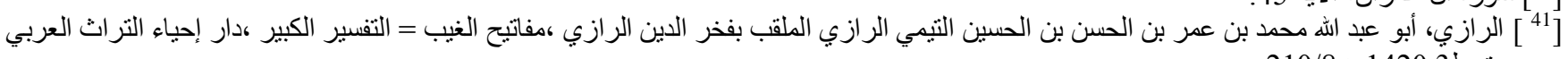

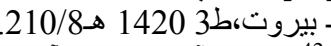




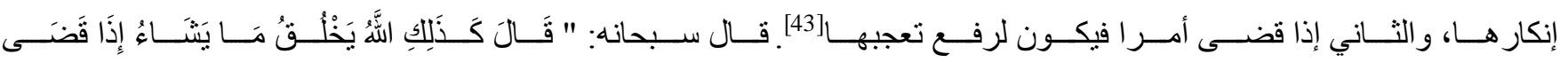
أَمْرًا فَإنَّمَا يَقُولُ لَهُ كُنْ فَيَكُون"[44].

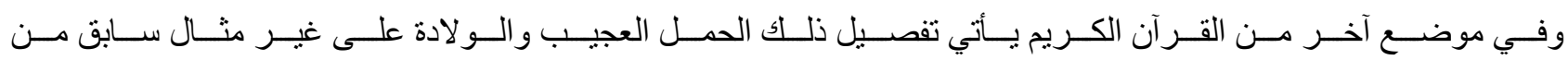

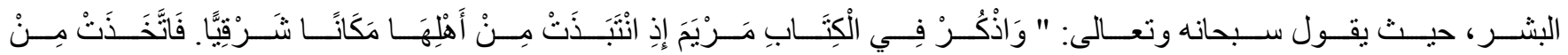

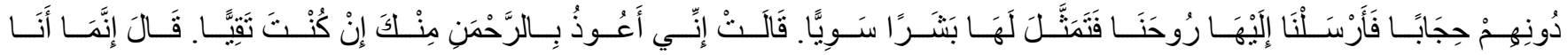

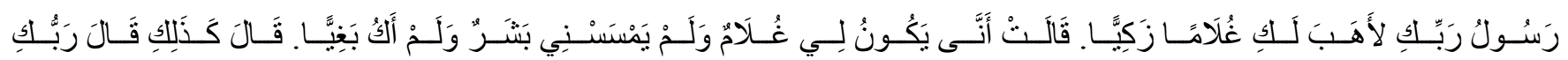

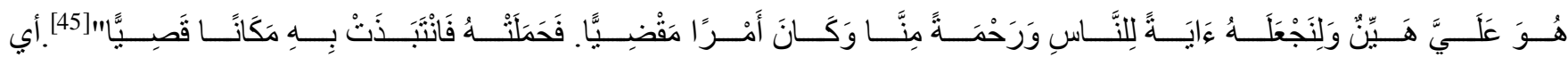

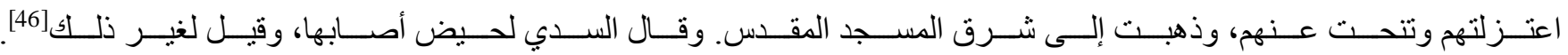

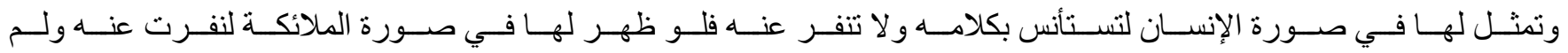
تقدر على استماع كلامه.[47]

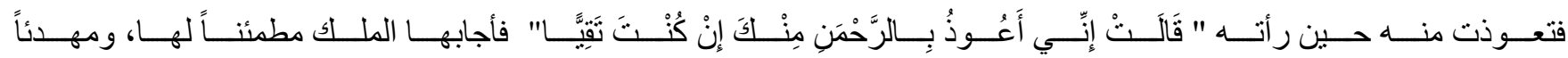

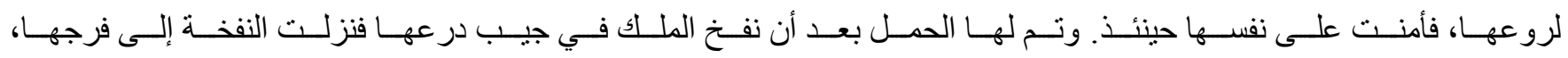

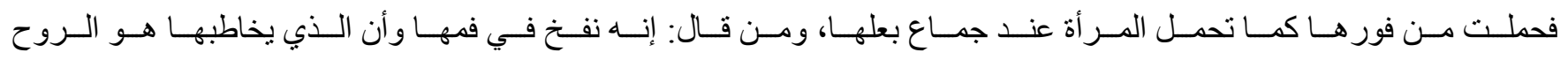

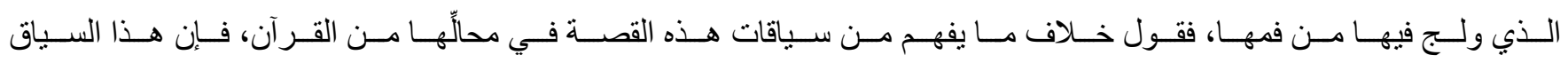

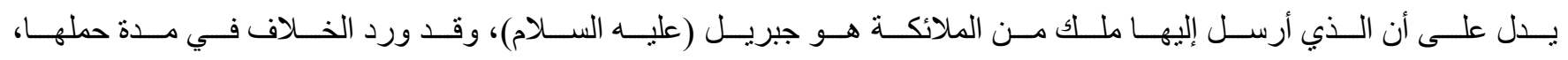
والمشهور عند الجمهور أنه تسعة اشهر.

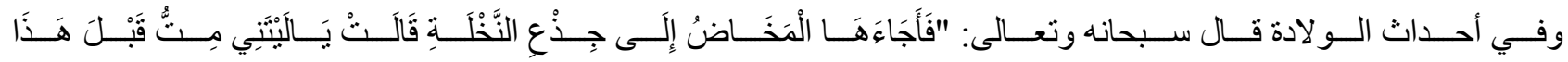

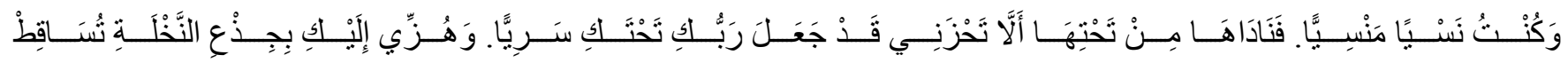

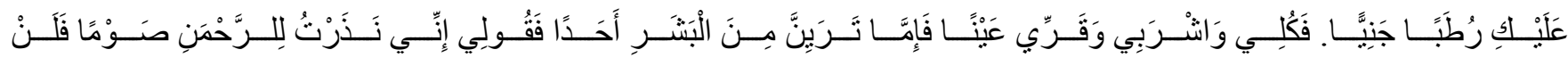

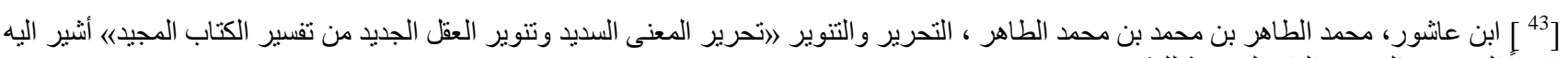

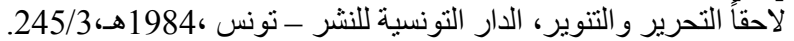

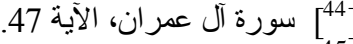

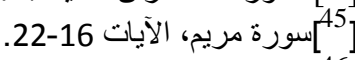

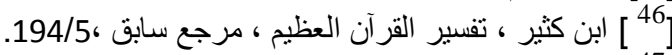
. 


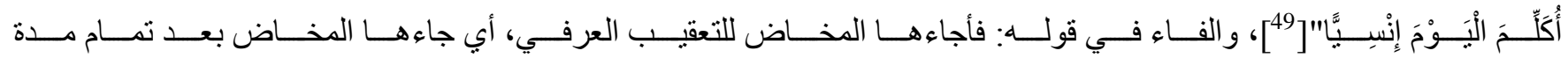

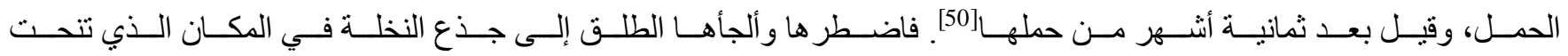

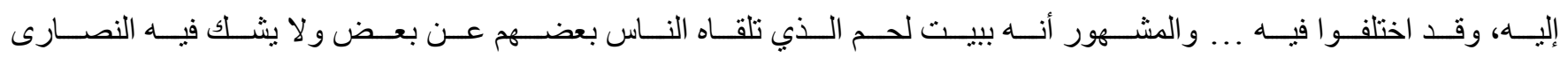

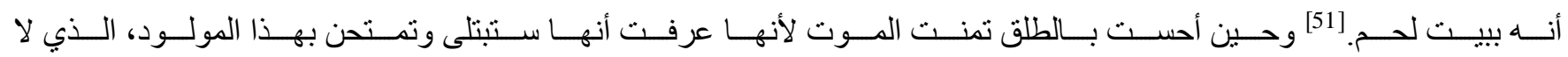

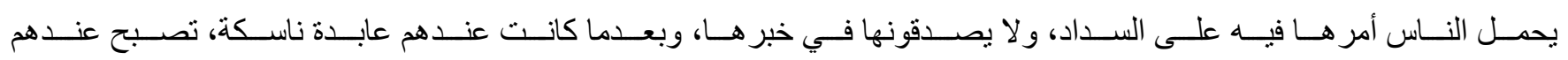

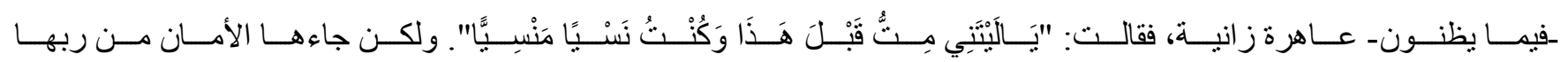

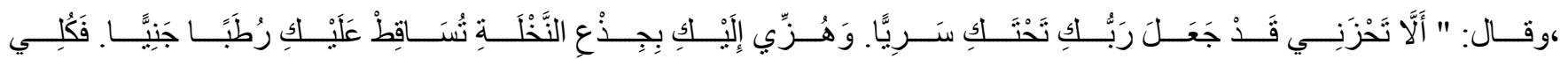

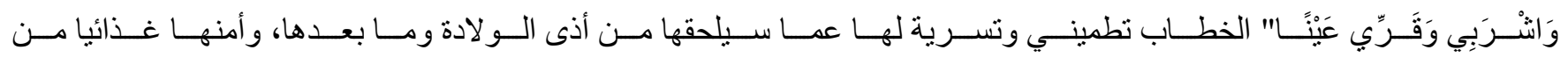

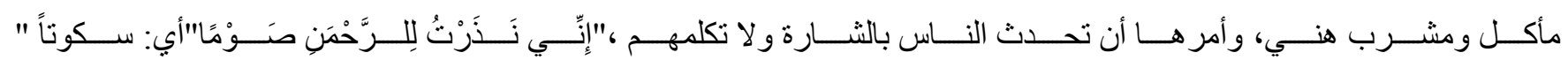

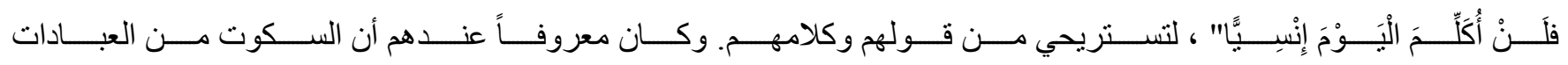

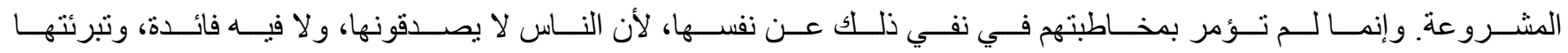
تكون بكلام الصبي في المهد.[52]

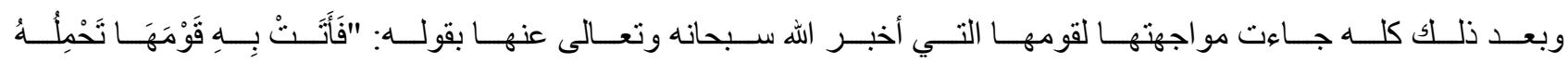

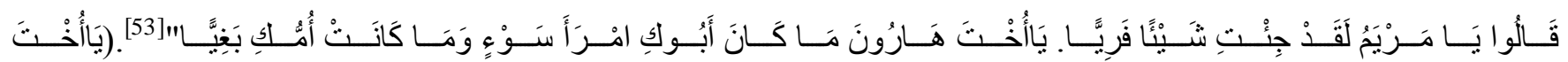

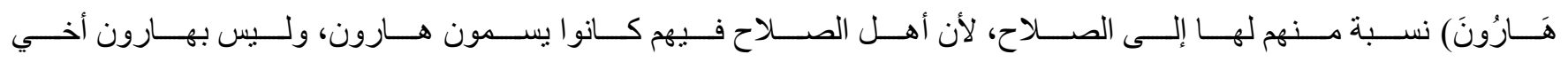

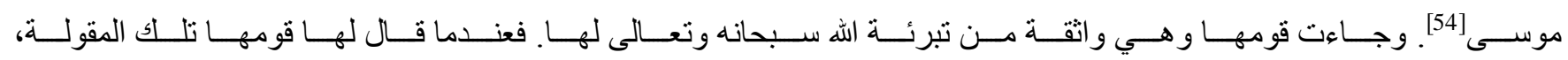

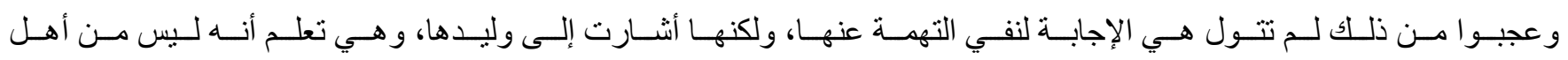

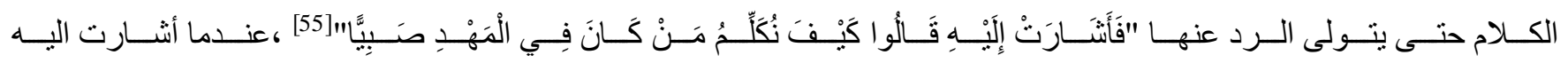

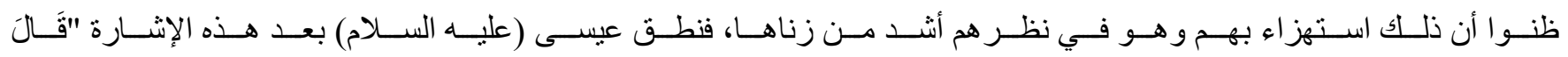

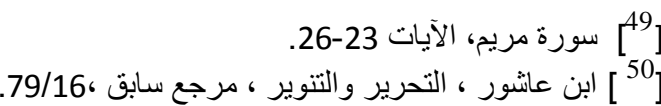

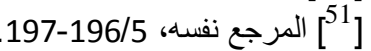

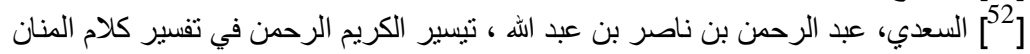

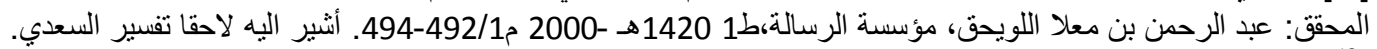

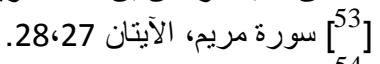

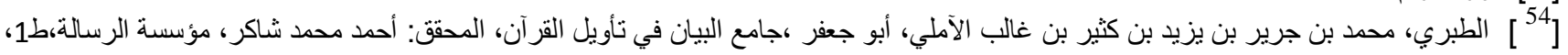




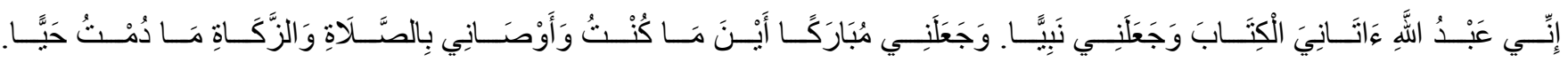

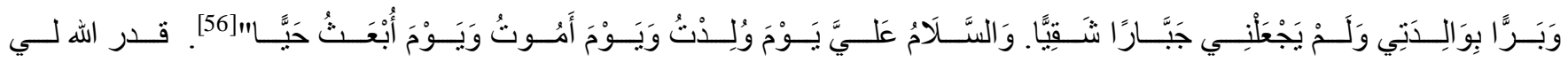

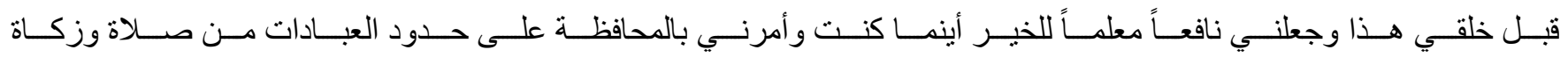

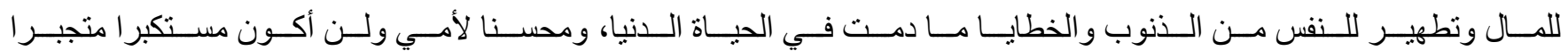
على الناس، مما بوحي ذلك ببركة ونز اهة أمه وطهارتها.[57

\section{المبحث الثاني: صفات عيسى عليه السلام في القرآن الكريم وفيه مطالب:}

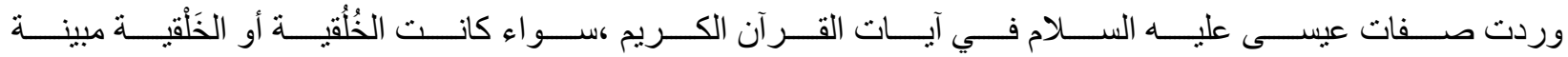
وداحضة إدعاء النصارى ألو هيته أو أنه ابن الله.

\section{المطلب الأول: الصفات الخَلقية:}

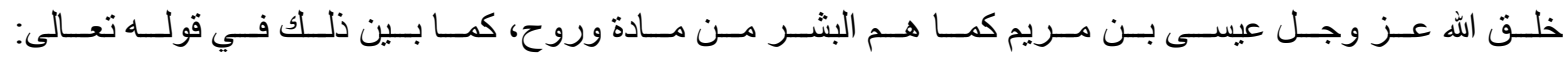

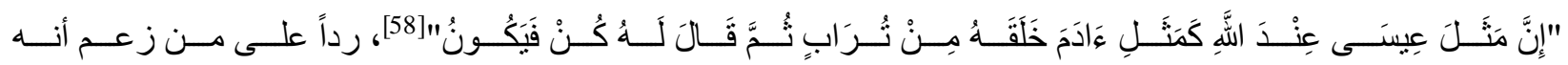

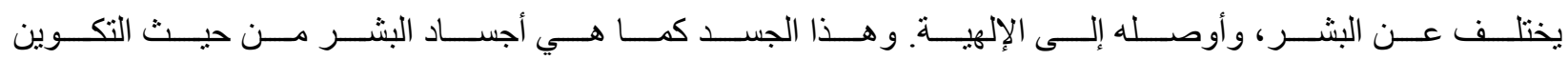

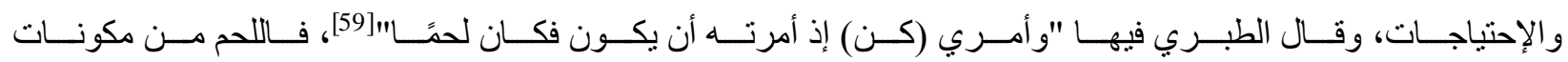
الجسم البشري، وما يلحق بذلك من شعر ودم وطول وقصر وتغذية.

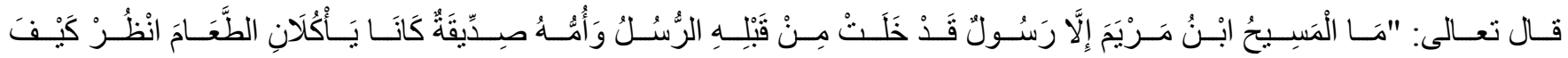

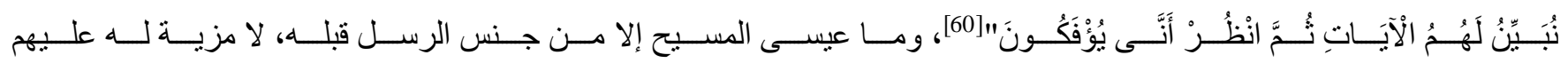

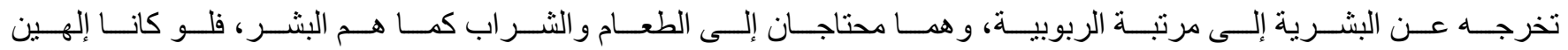
لاستغنيا عن الطعام والشراب.[61] ومما بين صفاته الخَلقية البشرية أحاديث في السنة المطهرة ،تبين الصفات الجسدية. 


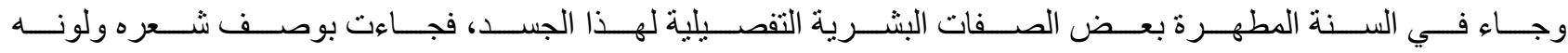
وقامته ونحو ذلك.

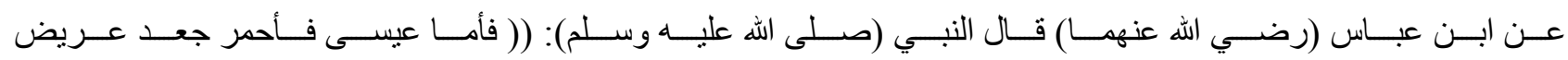

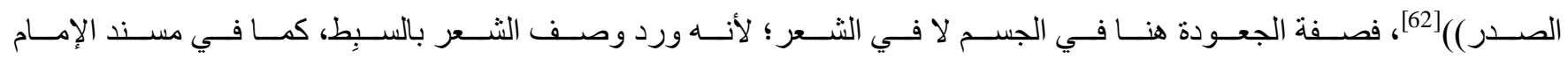

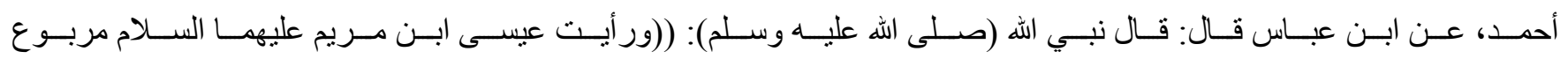

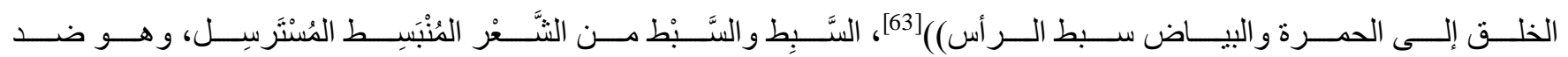
الجَعْد[64]، و وأما الجعد في الجسم فهو المجتمع الثنديد. [65] من هذه النصوص نخلص إلى أن ما ورد من صفاته الجسدية البشرية تتمثل في الآتي:-

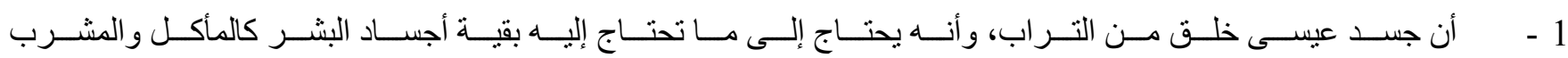
ونحوه.

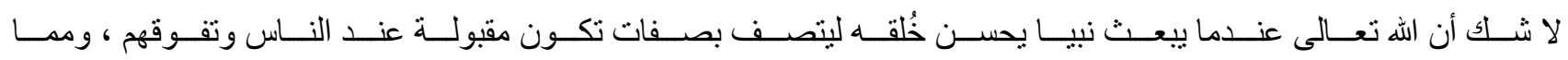
ورد من صفات عيسى عليه السلام ما يلي:-

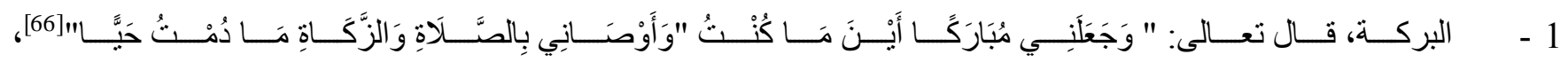

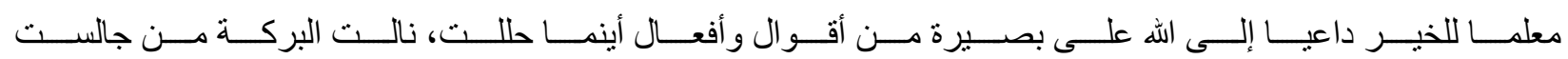




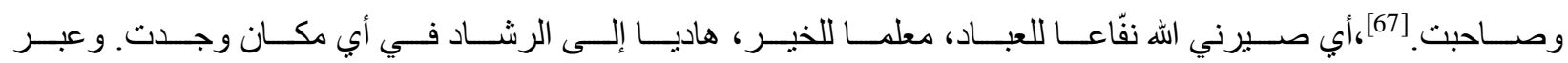

تعالى عن هذه الصفات بصيغة الماضي إشارة إلى تحققها وحدوثها فعلا في المستقبل.[68]

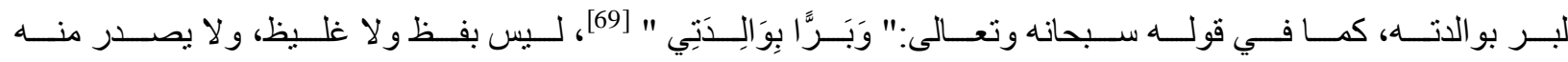

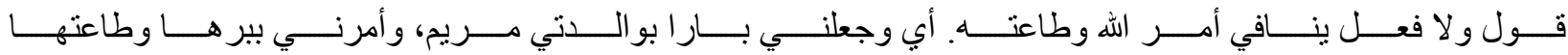

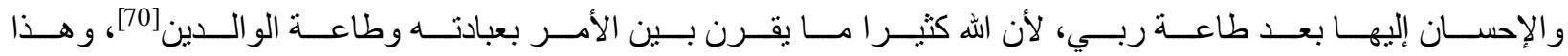

أيضا دليل على نفي الزنى عنها، إذ لو كانت زانية، لما كان الرسول المعصوم مأمور ا بتعظيمها.[71]

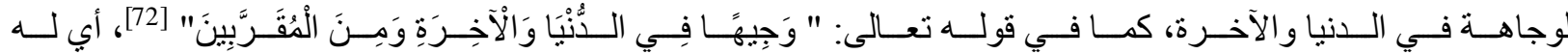

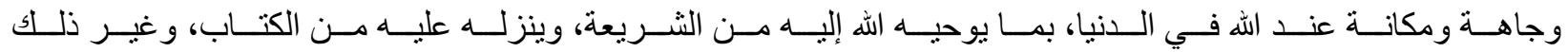

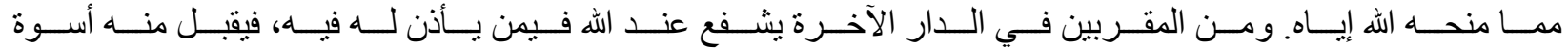
بإخو انه من أولي العزم صلوات الله وسلامه عليه و عليهم أجمعين]73].

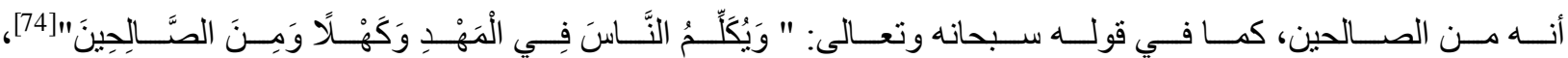

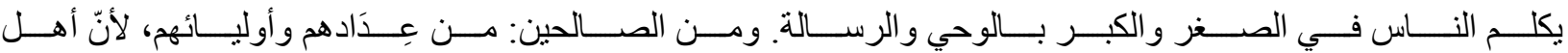
الصلاح بعضهم من بعض في الدين و الفضل.]75

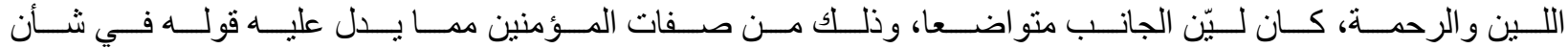

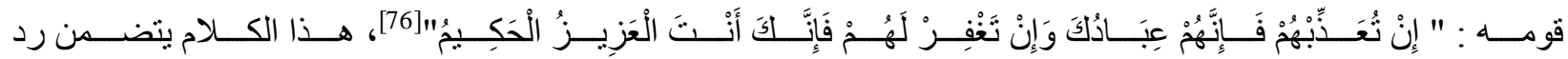

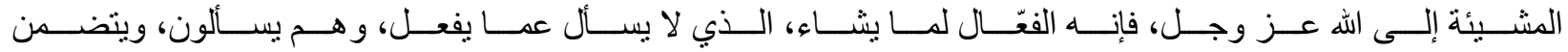

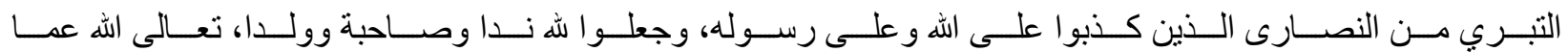

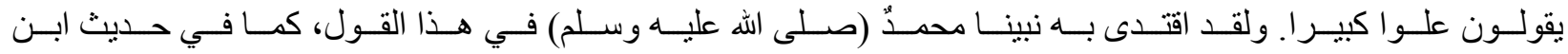

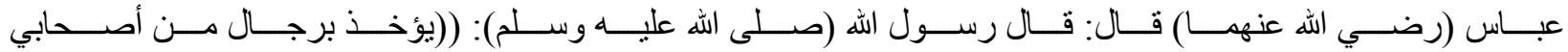

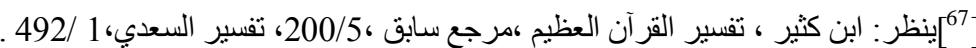

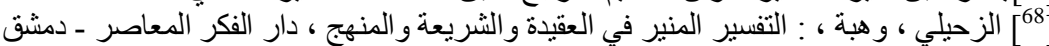

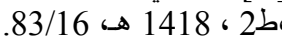

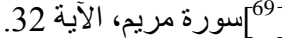

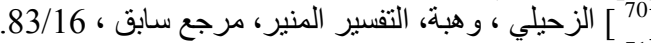

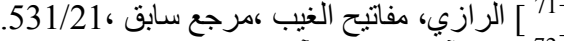

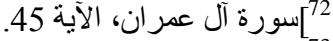
36/2.

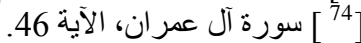

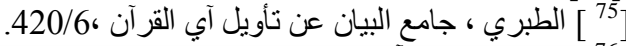




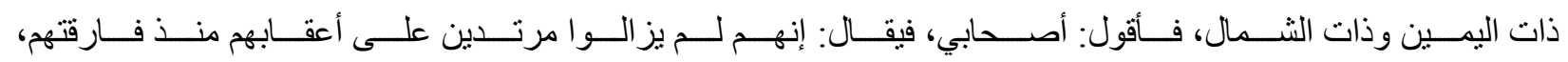

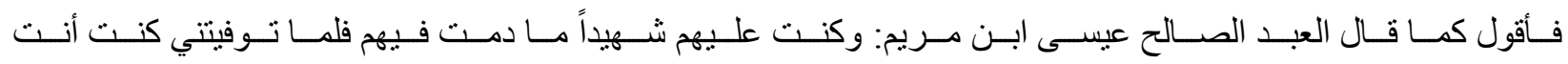

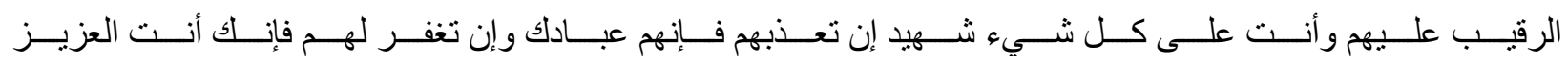
[77]. (الحكيم)

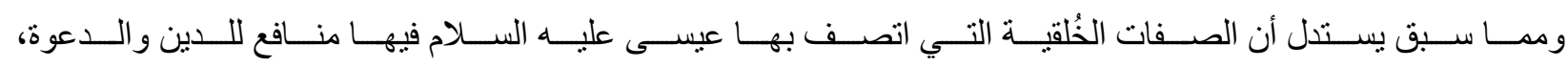
و استقامة سلوكه و أخلاقه، وبرّه بو الدته، و أنه ليس متكبر ا، صفات لابد للاعاة التحلي بها . 


\section{المطلب الثالث: الصفات الإضافية:}

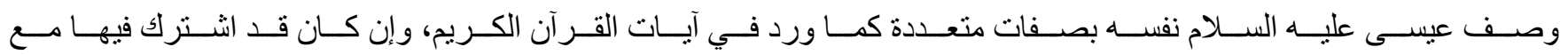
غير من الرسل، لابد من الاستئناس بها على سبيل الاقتداء: الصفة الأولى: الغلام الزكي:

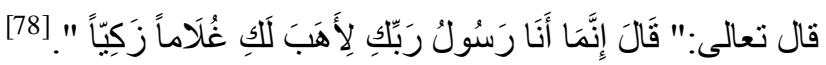
و الغلام الزكيّ: هو الطاهر من الذنوب 79، كر امة من الله لها.[80]

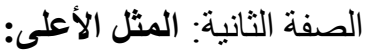

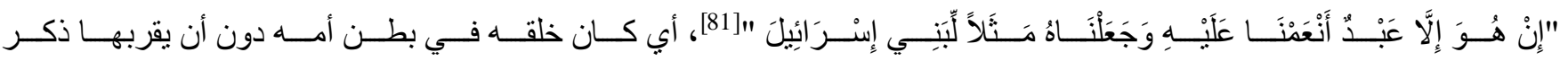

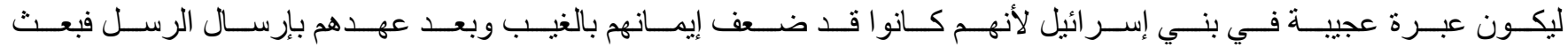
الله عيسى مجددا للإيمان بينهم، ومبر هنا بمعجز اته على عظم قدرة الله، ومعيدا لتشريف الله بني إسر ائيل.822] الصفة الثالثة: رحمة من الله:

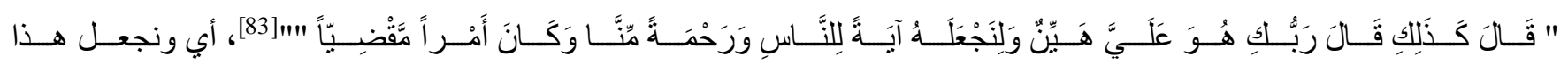
الغلام رحمة من الله ونبيا من الأنبياء، يدعو إلى عبادة الله تعالى وتوحيده. [84 الصفة الر ابعة: علم الساعة:

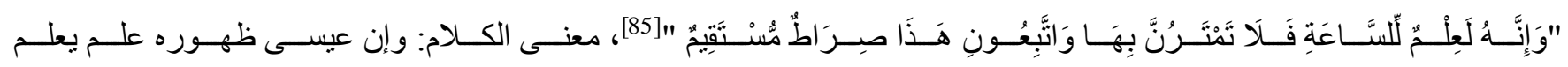
به مجيء الساعة، لأن ظهوره من أشر اطها ونزوله إلى الأرض دليل على فناء الدنبا، و إقبال الآخرة. [86] الصفة الخامسة: قوله: "إني عبد الله":

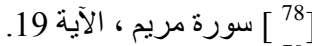
]

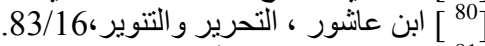
. 241/25، ابن عاشور التحرير و التنوير الآية

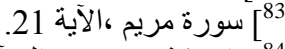

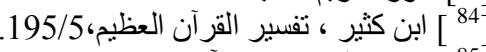
[85] 


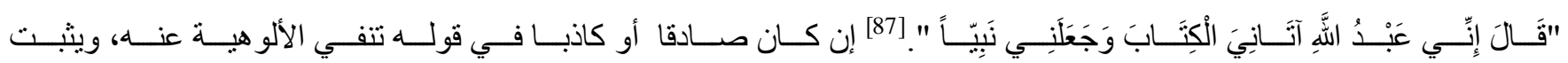

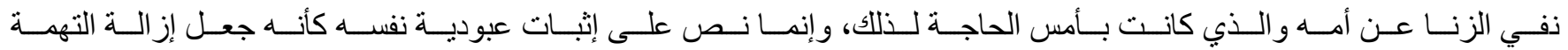
عن الله تعالى أولى من إزالة التهمة عن الأم، ثبت صدق ما حكاه الله تعالى عنه أنه قال: إني عبد الله.[88 الصفة السادسة: قول الحق:

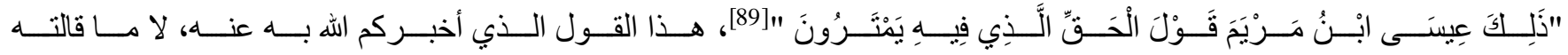

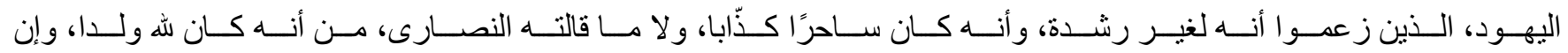
الله لم يتخذ ولدا، ولا ينبغي ذلك له. الصفة السابعة: آية للعالمين:

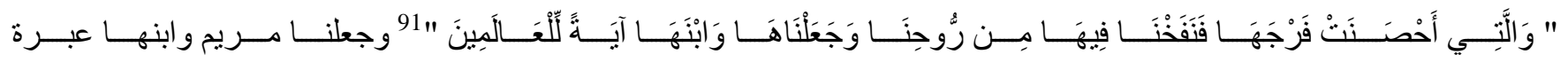
لعالمي زمانهما يعتبرون بهما ويتفكرون في أمر هما، فيعلمون عظيم سلطاننا وقدرتنا على ما نشاء. [92] الصفة الثامنة: روح من الله:

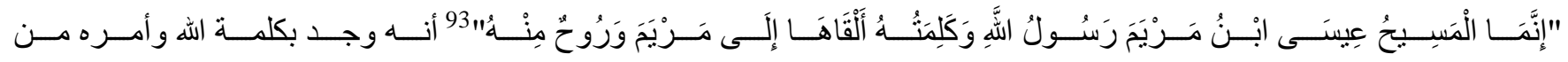
غير و اسطة و لا نطفة، وأضاف الروح إلى نفسه لأجل التشريف و التعظيم.[94] الصفة التاسعة: ايتاء الكتاب:

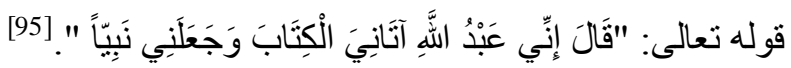

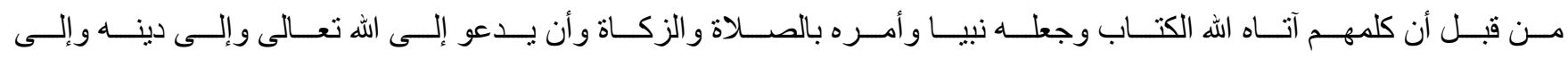

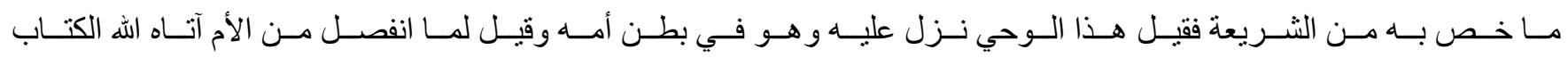




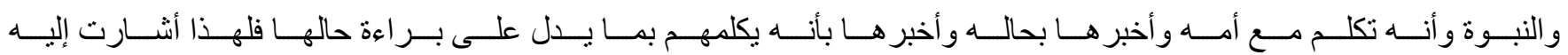
بالكلام.

الصفة العاشرة :النبوة:

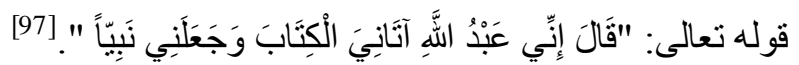

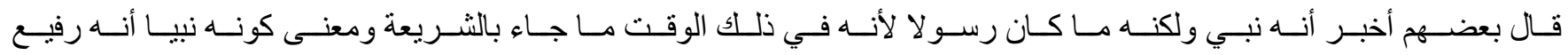

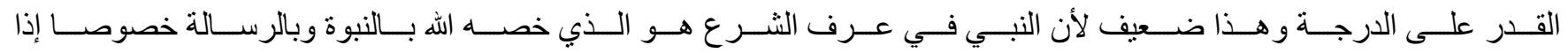
قرن إليه ذكر الشرع و هو قوله وأوصاني بالصلاة والزكاة. [98]

الصفة الحادية عشرة: الوصية:

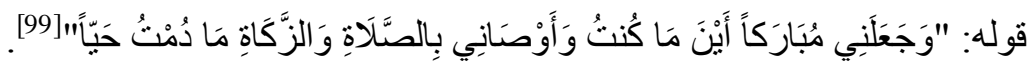

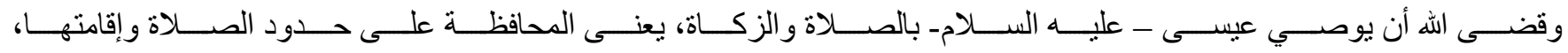

و أوصاني بترك الذنوب و اجتناب المعاصي.]100]

الصفة الثانية عثرة: عدم التكبر:

قوله: " وَلَمْ يَجْعَنْي جَبَّار اً شَقَقِيًا "[101]، أبي ولم يجعلني جبار ا مستكبرا عن عبادته وطاعتهـ[102]

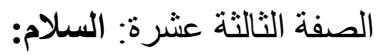

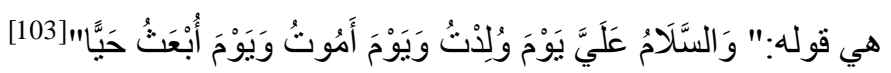

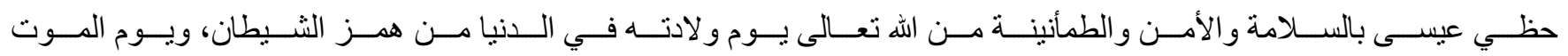

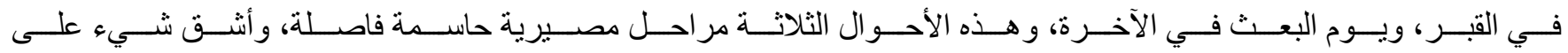
الناس. و السلام علي فكأنه قال وكل السلام علي و على أنباعي فلم ييق للأعداء إلا اللعن. [104] 
الصفة الرابعة عشرة :رفعه إلى السماء:

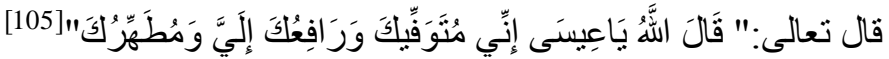

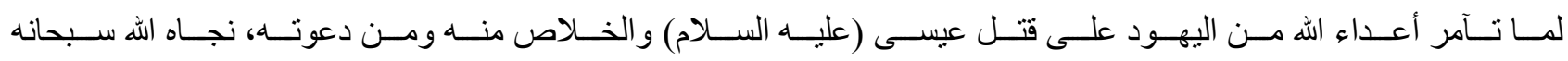

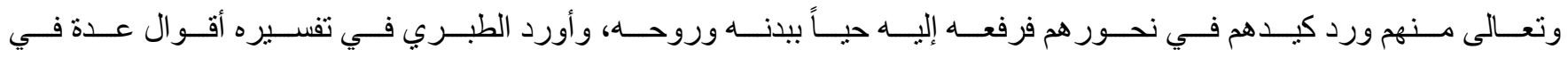
تبيان ما المقصود بـ(متوفيك) في هذه الآية، على النحو الآتي [106].-

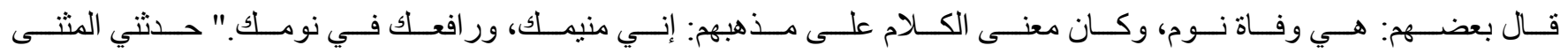

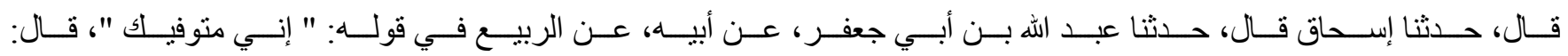
بعني وفاةً المنام".

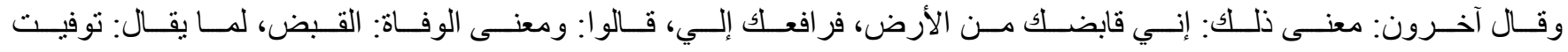

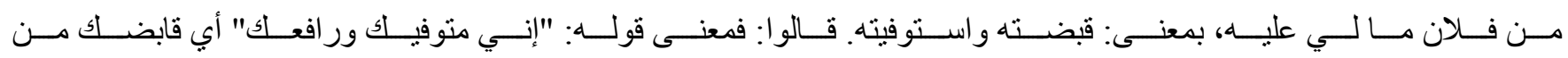

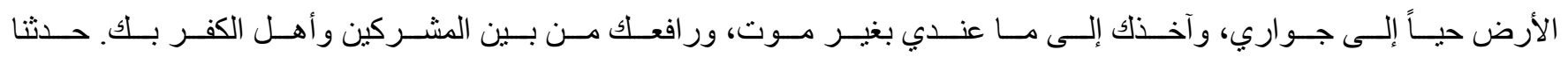

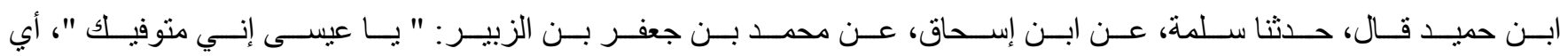
قابضُك.

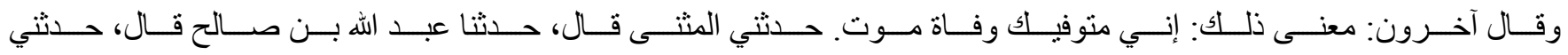
معاوية، عن علي، عن ابن عباس قوله: " إني منوفيك "، يقول: إني مميتك.

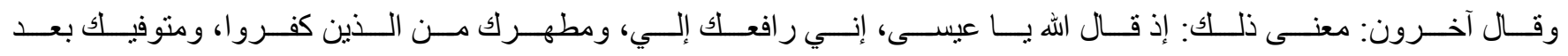
إنز الي إيالك إلى الدنيا. وقال: هذا من المقدم الذي معناه التأخير ، والمؤخر الذي معناه التقديم.

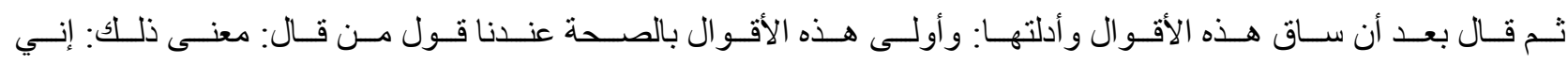

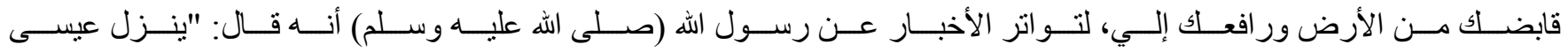

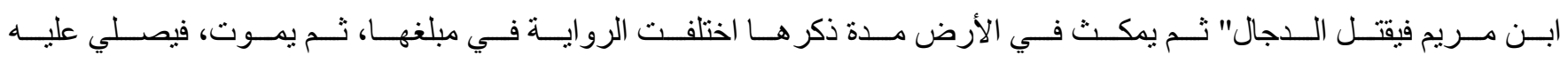

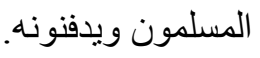




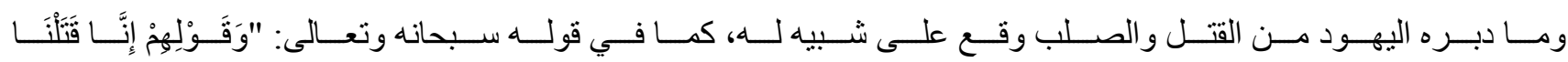

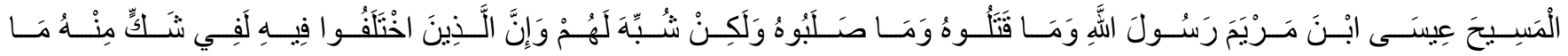

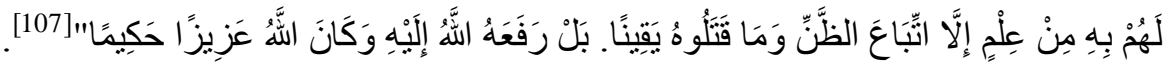

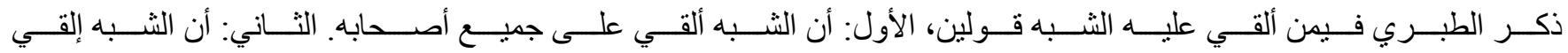

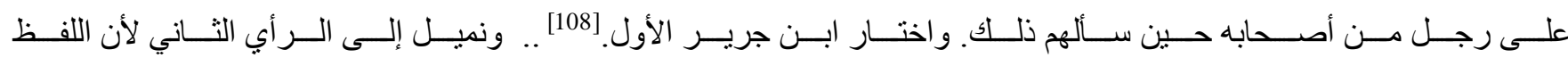
يدل على الواحد وليس المجموع. الصفة الخامسة عشر : نزوله في آخر الزمان:

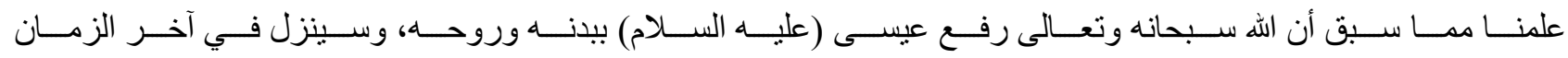

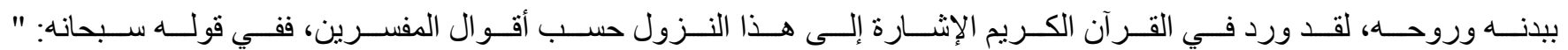

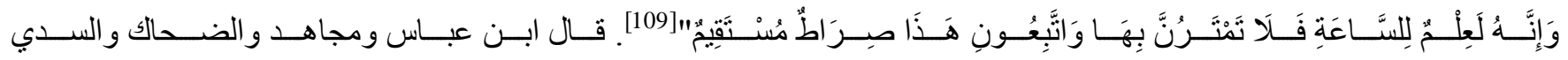

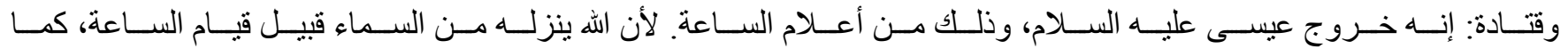
أن خروج الدجال من أعلام الساعة. [110]

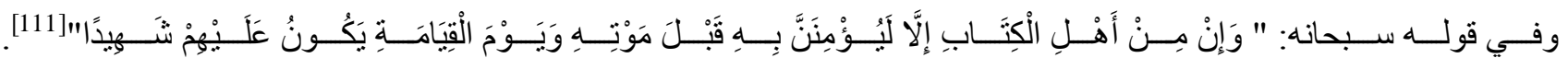

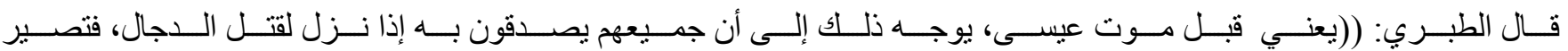

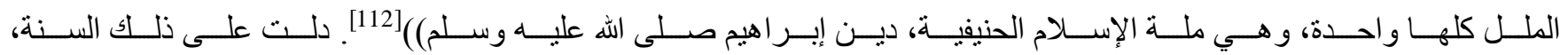

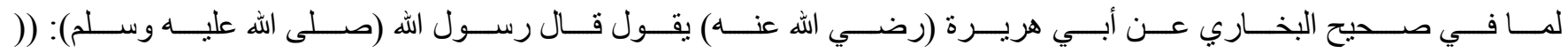

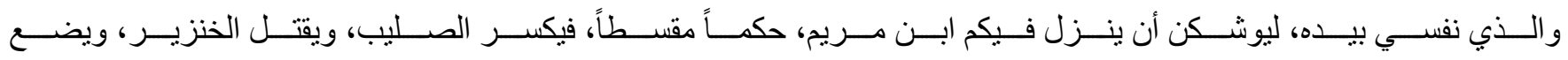
الجزية، ويفيض المال حتى لا يقبله أحد)(113] 


\section{الحكمة من نزوله:}

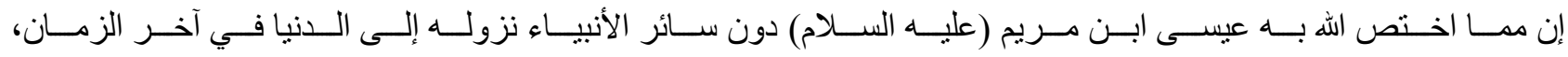

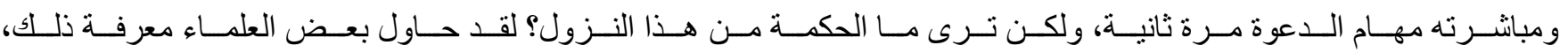
ومما قالوه في هذا الثأن ما يلي[114:-

$$
1 \text { - الرد على اليهود في زعمهم أنهم قتلوه، فبين تعالى كذبهم، و أنه الذي يقتلهم. }
$$$$
2 \text { - نزوله لدنو أجله ليدفن في الأرض إذ ليس لمخلوق من التراب أن يموت في غيرها. }
$$

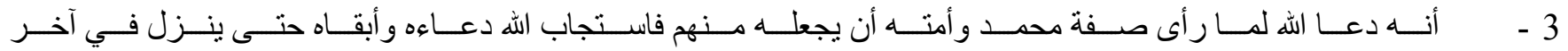

$$
\text { الزمان مجداً لأمر الإسلام فيو افق خروج الاجال فيقتله. }
$$

$$
4 \text { - تكذيبه لكل من ادعى إلهيته أو بنوته لله تعالى. }
$$

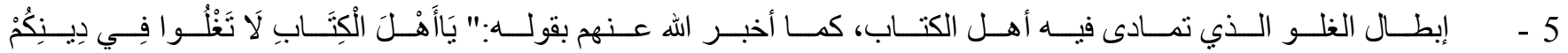

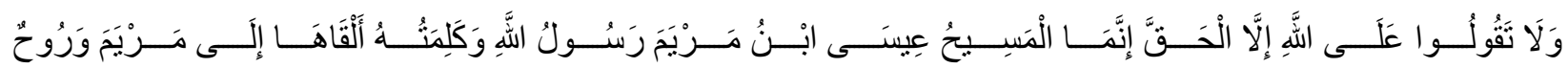
منْنْهُ [115] 
من خلال در اسة تفاسير الآيات القرآنية حول صفات أحد الأنبياء من أولي العزم من الرسل، عيسى عليه السلام في البحث، كانت بشرية عيسى واضحة وأنه خلق من تراب و إنما هو كلمة من الله القاها إلى مريم عليها السلام، يتصف بالصفات البشرية من حيث الخِلقة و الخُلق وما يتصف به الداعية الى الله، فهو مبارك نافع آمر بمعروف وناه عن منكر، بار بو الدته، ليس متكبرا و لا مستهنر ا ولا متجبرا على الخلق داعيا الى الله على بصيرة، أمر بالصلاة و الزكاة، مدخر عند ربه حتى يحين نزوله ويظهر الله الحق على يديه ويقتل الدجال ويكسر الصليب ويقتل الخنزير ويدعو برسالة محمد عليه الصلاة والسلام .

$$
\text { - نوصي المؤسسات الدعوية بناء برنامج نربوي أسري مستنبطا من سيرة الأنبياء وتعاملهم الأسري. }
$$

- سيرة الأنبياء من أولي العزم من الرسل، الأمة اليوم بأمس الحاجة للاطلاع عليها وتطبيق ما يستطيعون، لأن دعوة الله بحاجة للوحدة ورص الصفوف ونبذ الفرقة والخلاف . 
[2] النعماني، أبو حفص سرة آبة اج الدين عمر بن علي بن عادل الحنبلي الدمشقي ،اللباب في علوم الكتاب ،المحقق: الثشيخ عادل أحمد عبد

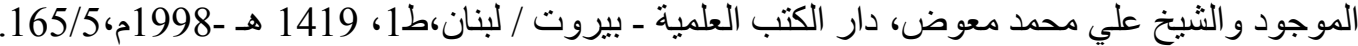

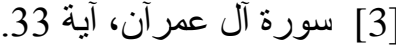
[4] ابن كثير ، أبو الفداء إسماعيل بن عمر بن كثير القرشي ، تفسير القرآن العظيم (ابن كثثر)،المحقق: محمد حسين شمس الدين، دار

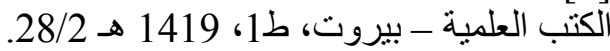

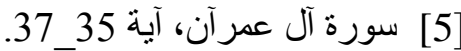
[6] بنظر: ابن كثير، تفيرة آن آية القرآن العظيم ، مرجع سابق، 33/2.

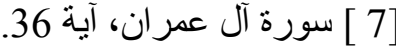

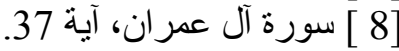

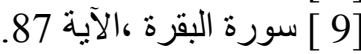

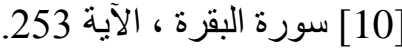

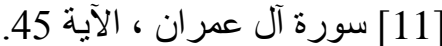
[12] سورة آل عمران، الآية 52 آل عمران [13 ] سورة آل عمران ، الآية 59.

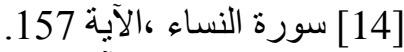
[15] سورة النساء ، الآية 171 سورة النساء 171. [16] سورة المائدة ، الآية 171 سورة الاية

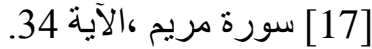
[18] سورة الزخرف سورة ، الآية [19] سورة الصف ، الآية 6. [20] سورة الصف ، الآية 14 الاية 14.

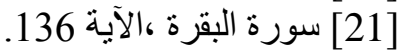
[22] سورة آل عمر ان، الآية 55 الإية [23] سورة آل عمران ، الآية84.

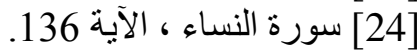
[25] سورة المائدة ،الآية78. سلاية الاية

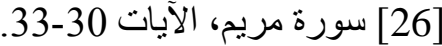

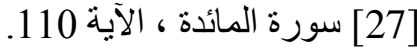

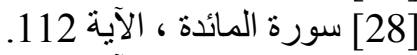

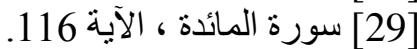
[30] سورة الأنعام، الآية 85 سورة الآنة

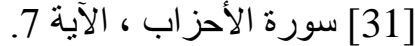
[32] سورة الثورى ، الآية 13 [32. [33] سورة آل عمران، الآية 45 سورة الثورية [34] الزمخشري ، أبو القاسم محمود بن عمرو بن الحمد، الكثناف عن حقائق غو امض التنزيل ، دار الكتاب العربي - بيروت ،ط3236/1407 هـ الزمهي. [35] ابن كثير ، تفسير القرآن العظيم، 36/2.

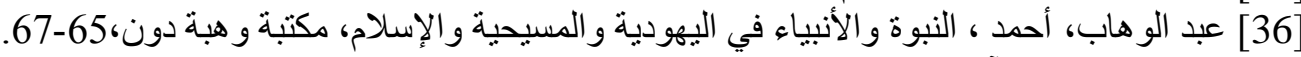

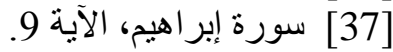
[38] الطيبي، شرف إير الدين الحسين بن عبد الله ،فتوح الغيب في الكثف عن قناع الريب (حاثشية الطيبي على الكثاف)،جائزة دبي الدولية

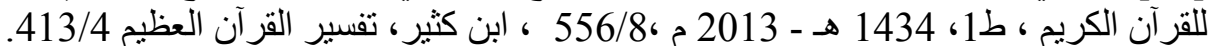

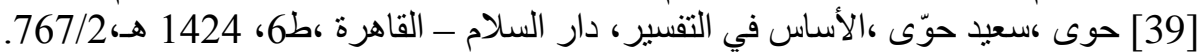

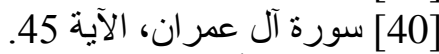
[41] الرازي، أبو عبد الله محمد بن عمر بن الحسب الحسن بن الحسين التيمي الرازي الملقب بفخر الدين الرازي ،مفاتيح الغيب = التفسير

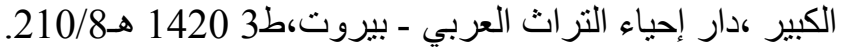




$$
\text { [42] سورة آل عمران، الآية } 47 .
$$

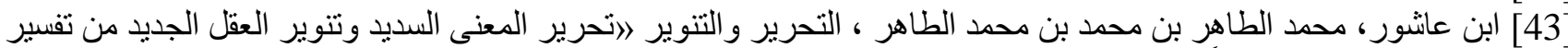

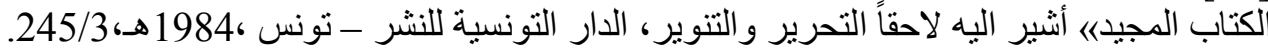

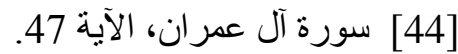

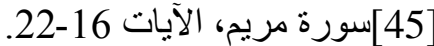

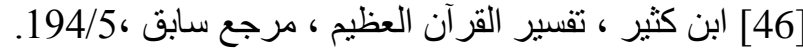

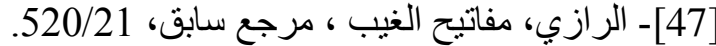

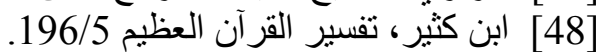

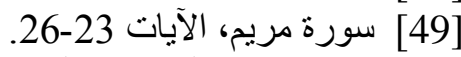

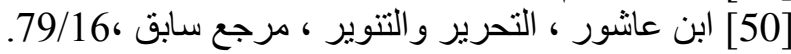

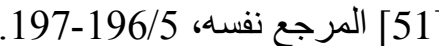

[52] السعدي، عبد الرحمن بن ناصر بن عبد الله ، تيسير الكريم الرحمن في تفسير كلام المنان

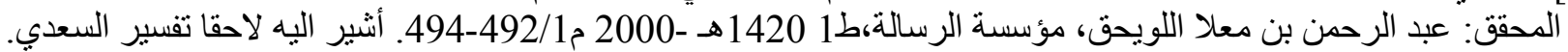

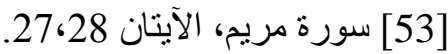

[54] الطبري، محمد بن جرير بن يزيد بن كثير بن غالب الآملي، أبو جعفر ،جامع البيان في تأويل القرآن، المحقق: أحمد محمد شاكر،

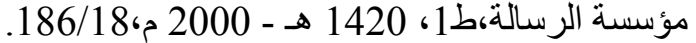

[55] [5ورة مريم، الآية 29.

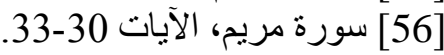

[57 [56 بنظر: الطبري ، جامع البيان عن تأوبل آي القرآن ، 186/18-192.

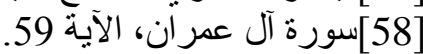

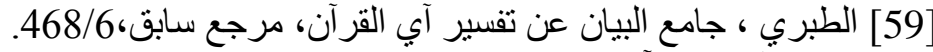

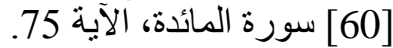

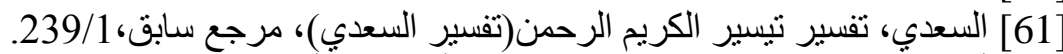

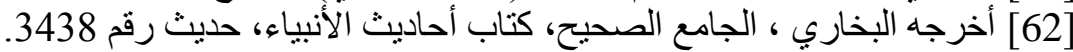

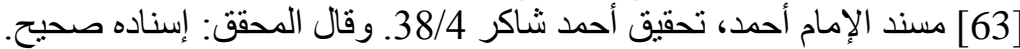

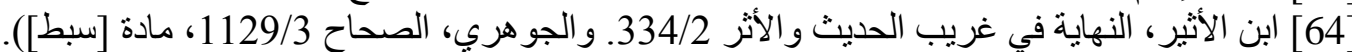

[65] [6ظر : ابن منظور ، لسان العرب 122/3، مادة [جعد]. وابن الأثير ، النهاية في غريب الحئ الحيث 275/1. وابن حجر، فتح الباري

$.486 / 6$

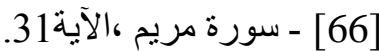

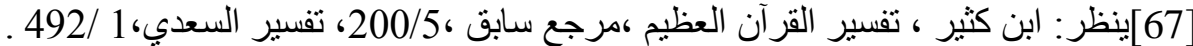

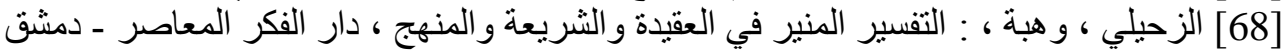

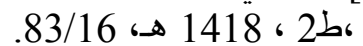

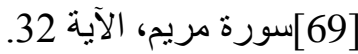

[70] الزحيلي ، وهبة، التفسير المنير، مرجع سابق ، 832/16.

[71] الرازي، مفاتيح الغيب ،مرجع سابق ، الزئ ،

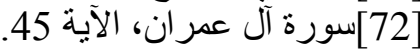

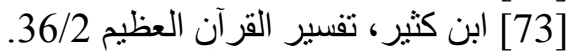

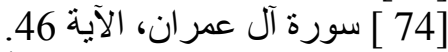

[75] الطبري ، جامع البيان عن تأويل آي القرآن ،420/6.

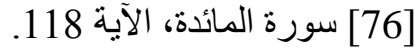

[77] ابن كثير ، تقسير القرآن العظيم ،مرجع سابق ،210/3.

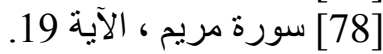

[79] الطبري ، جامع البيان عن تأويل آي القر آن ،164/18.

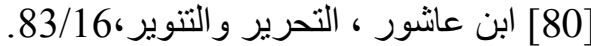

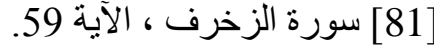

[82] [8ن عانثور التحرير والتنوير ، 241/25.

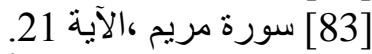

[84] ابن كثير ، تفسير القر آن العظيم،195/5. 


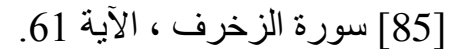

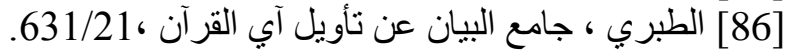

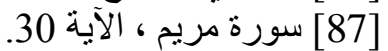

[88] [878] الرازي ، مفاتيح الغيب، 341/21.

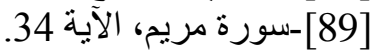

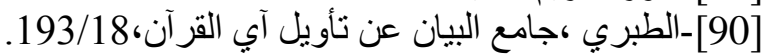

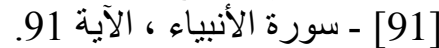

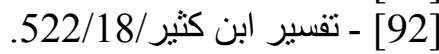

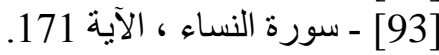

[954] ] - الر ازي مفاتيح الغيب، 270/11.

[95] سورة مريم، الآية

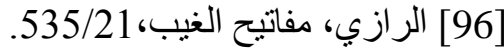

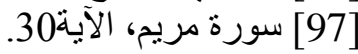

[98] [98] الر ازي ، مفاتيح الغيب، 535/21.

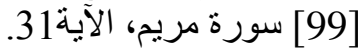

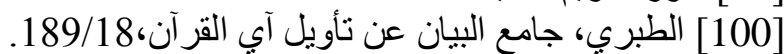

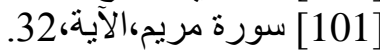

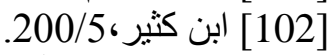

[103] سورة مريم،الآية

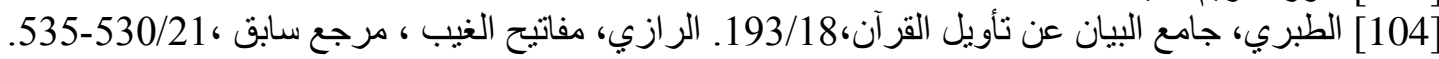

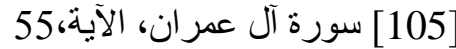

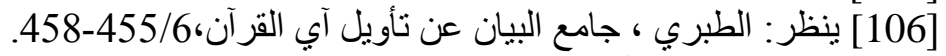

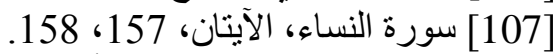

[108] [108] الطبري ، جامة النساء البيان، عن تأويل آي القرآن 367/9-368.

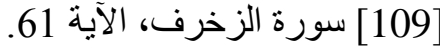

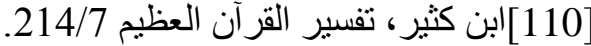

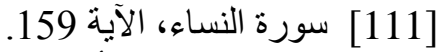

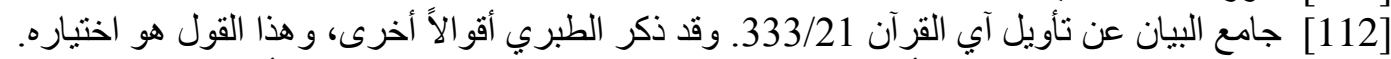

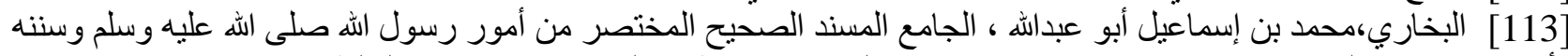

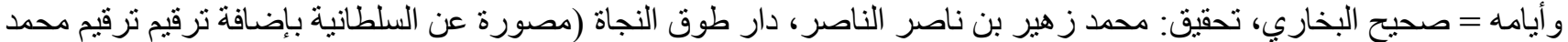

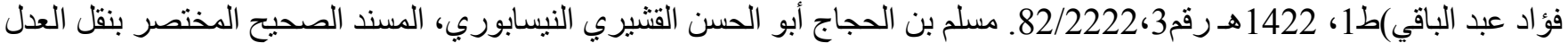

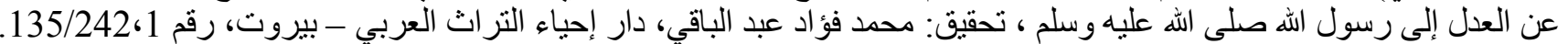

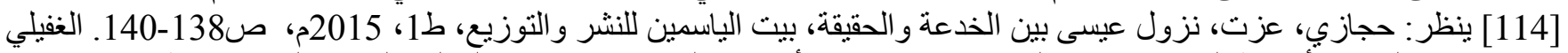

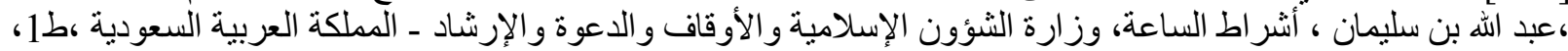
23-21422 142

[115]سورة النساء، الآية 141. 